\title{
PROTEÇÃO DA PERSONALIDADE NO AMBIENTE DIGITAL: UMA ANÁLISE À LUZ DO CASO DO ASSIM CHAMADO DIREITO AO ESQUECIMENTO NO BRASIL ${ }^{1}$
}

\author{
PROTECTION OF PERSONALITY IN THE DIGITAL ENVIRONMENT: AN ANALYSIS IN THE LIGHT \\ OF THE CASE OF THE SO-CALLED RIGHT TO BE FORGOTTEN IN BRAZIL
}

Ingo Wolfgang Sarlet ${ }^{2}$

\begin{abstract}
Resumo: Tendo em conta que os direitos da personalidade são particularmente vulneráveis no contexto da assim chamada era digital, designadamente em face do impacto das cada vez mais sofisticadas tecnologias de informação, e que a capacidade do Direito, na condição de estrutura normativo-regulatória, de fornecer respostas com a necessária rapidez e um mínimo de eficácia, também está cada vez mais colocada à prova. Um dos problemas que tem sido, também no caso brasileiro, de particular atualidade e relevância, diz respeito ao conflito entre as liberdades de expressão e de informação e os direitos de personalidade, assumindo aqui destaque a controvérsia em torno do reconhecimento do assim chamado direito ao esquecimento. Nessa perspectiva, partindo da premissa de que tal direito encontra fundamento na ordem jurídica brasileira na condição de um direito fundamental implícito, com o presente texto visa-se, mediante uma análise crítica das principais decisões dos Tribunais Superiores brasileiros, discutir e avaliar os aspectos mais relevantes concernentes ao conteúdo e limites do direito ao esquecimento na internet e dos critérios utilizados para a sua aplicação em casos concretos. Palavras-chave: Direitos de personalidade. Internet. Direito ao esquecimento. Tribunais superiores brasileiros.
\end{abstract}

\begin{abstract}
Personality rights are particularly vulnerable within the context of the so-called digital age, mostly because of the impact of increasingly sophisticated information technologies. At the same time, the Law has been submitted to probation as a regulatory framework, more and more challenged in its capacity to provide answers with necessary efficacy and speed. One of the most significant concern, also in the Brazilian case, is how to deal with the traditional (but still relevant) clash between fundamental freedom of speech and information in face of personality rights, with outstanding importance to the controversy regarding the recognition of the so-called right to be forgotten. Based on the premise that the right to be forgotten might be justified as an implicit fundamental right in the Brazilian constitutional order, this paper aims, through a critical analysis of the Superior Court's rulings, to discuss and assess the most significant aspects related to the content and limits of the right to be forgotten on the internet as well as the criteria adopted to apply such right in practical cases.
\end{abstract}

Keywords: Personality rights. Internet. Right to be forgotten. Brazilian Superior Courts.

\footnotetext{
1 Agradeço ao Instituto Max-Planck de Direito Privado Estrangeiro e Internacional de Hamburgo pela possibilidade ímpar de ter podido realizar parte da pesquisa (e redação de parte do texto) que resultou na elaboração do presente artigo, seja no período de janeiro e fevereiro de 2017 (na condição de bolsista do Instituto), seja durante os meses de janeiro e fevereiro de 2018, com auxílio oriundo de projeto de pesquisa e intercâmbio acadêmico no âmbito do Programa PROBRAL (DAAD-CAPES) coordenado por mim e pela Professora Dra. Marion Albers, da Universidade de Hamburgo.

2 Pós-Doutor pela Ludwig-Maximilians-Universität München, LMU, Alemanha; Doutor em Direito pela Ludwig Maximillians Universität de Munique, Alemanha; Professor Titular da Faculdade de Direito e dos Programas de Mestrado e Doutorado em Direito e em Ciências Criminais da Pontifícia Universidade Católica do Rio Grande do Sul; Avenida Ipiranga, 6681, Prédio 11, $10^{\circ}$ andar, Partenon, 90619-900, Porto Alegre, Rio Grande do Sul, Brasil; iwsarlet@gmail.com; https://orcid. org/0000-0002-2494-5805
} 


\section{Introdução}

Considerando que a proteção da dignidade da pessoa humana e dos direitos de personalidade representa em face dos avanços tecnológicos, em especial no campo das tecnologias da informação e ligadas ao ambiente da internet, um problema central para a ordem política, econômica e jurídica (sem prejuízo das questões de natureza cultural, sociológica, filosófica e antropológica), também a discussão sobre o assim chamado direito ao "esquecimento" - a exemplo do que ocorreu na Europa e EUA - não tardou a chamar a atenção da doutrina e jurisprudência brasileiras.

Embora os problemas relacionados com a proteção dos direitos humanos e fundamentais nesse contexto assumam uma repercussão mundial e transnacional, ultrapassando as fronteiras territoriais dos estados e exigindo também respostas e soluções compatíveis, existem peculiaridades respeitantes aos diversos estados que devem ser levadas em conta. Por tal razão, será priorizada uma compreensão constitucionalmente adequada, ou seja, afinada com as peculiaridades do sistema jurídico brasileiro, sem descuidar de algumas referências ao direito internacional e estrangeiro, quando relevantes para a compreensão, desenvolvimento e crítica da evolução do tema e do seu tratamento no Brasil.

Antes de avançar-se, contudo, indispensável uma breve anotação, ainda nessa fase introdutória, no que diz com a origem, terminologia e conceituação do assim chamado direito ao esquecimento, aspectos que por si só não são objeto de consenso. Imperioso, portanto, estabelecer aqui alguns acordos semânticos e premissas a guiar as considerações subsequentes.

Tanto do ponto de vista terminológico quanto conceitual, a noção de um direito ao esquecimento ou direito a ser esquecido, como preferido em língua inglesa (right to be forgotten) e alemã (recht auf vergessen werden), apesar de sua disseminação mais recente, não é em si nova, encontrando-se algumas referências diretas relativamente antigas, seja em decisões judiciais, seja na literatura. $^{3}$

No direito estrangeiro (tanto na literatura quanto na esfera jurisprudencial) a noção de um direito ao esquecimento teria sido utilizada na França quando do julgamento do conhecido caso Landru (TGI - Tribunal de Grand Instance Seine), em 14 de outubro de 1965, e confirmada em sede de apelação, bem como numa decisão datada de 20 de março de 1983 pelo TGI Paris. ${ }^{4}$ Na literatura, calha referir, igualmente em caráter ilustrativo, os textos de Agathe Lepage (2001, p. 2079) e de Théo Hassler (2007, p. 2829), bem como a obra monográfica de Viktor Mayer-Schönberger (2009), que em muito contribuiu para a difusão do termo.

\footnotetext{
3 Note-se que, em termos gerais, aspectos relevantes do que atualmente se entenda ser objeto de proteção de um direito ao esquecimento já podem ser encontrados em decisões bem mais antigas, que, todavia, não fazem menção direta a tal direito. Esse é o caso, nos EUA, nos anos 1930 (julgado pela Corte de Apelação da Califórnia, em 1931), e do mais difundido caso Lebach, julgado em 1973 pelo Tribunal Constitucional Federal da Alemanha, ambos envolvendo a proteção da personalidade e um direito à ressocialização (CACHAPUZ; CARELLO, 2015, p. 327 e ss.).

4 Cf. Heylliard (2012, p. 10).
} 
Mas foi o caso Google vs. Agência espanhola de proteção de dados e Mário Costeja Gonzalez, julgado pelo Tribunal de Justiça da União europeia (TJUE) em 2014 (CARELLO, 2018, p. 45 e ss.), que acabou dando visibilidade internacional ao direito ao esquecimento, ainda que no julgado propriamente não se tenha feito menção ao termo.

De lá para cá, o assim chamado direito ao esquecimento ganhou notoriedade mundial, mas as questões de fundo e os problemas ao mesmo tempo relacionados também se avolumaram.

No caso do Brasil, igualmente se encontram importantes registros na doutrina e que remontam aos anos 1990 (RODRIGUES JUNIOR, 2013). Já no que diz com a jurisprudência nacional, é de sublinhar que mesmo antes da decisão Google do TJUE o direito ao esquecimento já havia sido reconhecido pelo Superior Tribunal de Justiça (STJ), designadamente em maio de 2013, no julgamento que ficou conhecido como caso chacina da candelária, e que atraiu intensa polêmica e mobilizou os meios de comunicação e a academia jurídica. ${ }^{5}$

No que toca à esfera legislativa, da regulamentação normativa de um direito ao esquecimento, não há como deixar de referir o documento da União Europeia de novembro de 2010 (A comprehensive approach to data protection in the European Union), que refere a necessidade de assegurar um direito ao esquecimento e mesmo sugerindo uma definição, ${ }^{6}$ bem como a menção do direito ao esquecimento no projeto de um novo regulamento geral sobre proteção de dados na União Europeia de março de 2012. Tal previsão acabou constando no Regulamento Geral de Proteção de Dados europeu aprovado em março de 2016 (679/2016) e com início de vigência previsto para 25 de maio de 2018 (UNIÃO EUROPEIA, 2016). No artigo 17, o novo regulamento dispõe sobre um direito ao "apagamento" (right to erasure) de dados (expressamente associado a um direito ao esquecimento - right to be forgotten) e estabelece parâmetros para a sua aplicação.7

Por tais razões é que não tardou mais para que o termo direito ao esquecimento (ainda que tecnicamente não o mais adequado ${ }^{8}$ ) acabasse sendo disseminado e amplamente utilizado, incorporando-se à linguagem corrente, na mídia, na literatura e na jurisprudência em várias línguas. Aliás, a figura do direito ao esquecimento - e o caso brasileiro revela isso - tem sido mesmo associada a situações que nem sempre guardam direta relação com o seu objeto e onde antes e durante muito tempo sequer se falava em tal direito.

\footnotetext{
5 V. Caso Chacina da Candelária julgado pelo Superior Tribunal de Justiça em 2013 e que ainda será objeto de especial atenção. Cf. Brasil (2013a).

6 "clarifying the so-called 'right to be forgotten', i.e. the right of individuals to have their data no longer processed and deleted when they are no longer needed for legitimate purposes." Note-se, contudo, que tal documento - ao contrário do que se encontra referido em algumas publicações - não consiste em uma Diretiva ou Regulamento, mas, sim, em uma espécie de carta de intenções na forma de uma comunicação da Comissão Europeia ao Parlamento Europeu, a respeito da necessidade de uma nova e mais eficaz regulamentação da matéria.

7 "Article 17 Right to erasure ('right to be forgotten') 1. The data subject shall have the right to obtain from the controller the erasure of personal data concerning him or her without undue delay and the controller shall have the obligation to erase personal data without undue delay where one of the following grounds applies:"

8 Note-se que sob o rótulo de um direito ao esquecimento do que se trata - em termos técnicos - é basicamente assegurar aos indivíduos um direito a obter o cancelamento, mas também a não divulgação e/ou dificuldade do acesso a determinadas informações (como se verifica nos pedidos de desindexação junto aos provedores de busca/pesquisa da internet).
} 
Da mesma forma, quando se verifica - pelo menos no Brasil - que em vários casos concretos levados ao poder judiciário, a invocação de um direito ao esquecimento não envolve um pedido de proibiçãa de divulgação de determinada informação (ou mesmo de desindexação dos mecanismos de busca da internet), mas, sim, uma reparação de danos imateriais e mesmo materiais, sequer se está a inibir ou impedir o acesso pelo público aos fatos (informações) tidos como prejudiciais.

Todavia, compreendendo o direito ao esquecimento em sentido amplo (mais abrangente do que o direito ao esquecimento na internet) a responsabilização de quem de modo abusivo veicula alguma informação ou mesmo o reconhecimento de um direito de resposta acabam, de algum modo, operando como fatores que podem levar a uma maior contenção (ou mesmo não reiteração) quando do exercício da liberdade de expressão e de informação.

Que isso não significa que inexistem aspectos controversos a serem equacionados precisamente no que diz respeito aos limites da liberdade de expressão e dos direitos de personalidade - é algo que aqui não será objeto de atenção. A despeito disso, é necessário estabelecer um acordo semântico, de tal sorte que também aqui se utilizará a terminologia usual, ou seja, direito ao esquecimento.

Assim, tal como já anunciado no próprio título, é possível delimitar o objeto do presente texto, qual seja, o da proteção da personalidade e dos direitos fundamentais que lhe são conexos no ambiente da internet, tendo como foco o assim chamado direito ao esquecimento na ordem jurídico-constitucional brasileira e à luz da jurisprudência dos tribunais superiores, designadamente do Superior Tribunal de Justiça (STJ) e do Supremo Tribunal Federal (STF).

Partindo-se do pressuposto de que o assim chamado direito ao esquecimento, na condição de direito fundamental, corresponde a uma dimensão concreta (ainda que apenas relativamente autônoma) dos direitos de personalidade, o que se pretende demonstrar é que o direito ao esquecimento, quanto ao seu conteúdo e alcance, apenas pode ser adequadamente concretizado no contexto das tensões (e mesmo colisões) entre a proteção e a promoção dos direitos de personalidade e das liberdades de expressão e de informação, incluindo aqui o direito à informação e os assim chamados "direitos" à memória e à história, ademais do princípio democrático nas suas diversas refrações.

Para tanto, iniciar-se-á com uma breve análise da justificação jurídico-constitucional do reconhecimento de um direito ao esquecimento na condição de direito fundamental (implícito) em sentido material e formal, para, na sequência, demonstrar, à luz da experiência legislativa e jurisprudencial brasileira, o modo mediante o qual um direito ao esquecimento tem sido compreendido e concretizado até o presente momento, em especial no que diz com o domínio da internet, seguindose uma apreciação sistemática e crítica sobre o conteúdo e limites do direito ao esquecimento no Brasil - o que inclui o problema dos critérios para a sua aplicação, ademais de - na fase conclusiva - algumas considerações a respeito de alguns dos principais desafios a serem equacionados.

Convém sublinhar, outrossim, que não se pretende aqui em hipótese alguma inovar no sentido de "reinventar a roda", mas, sim, com base na apresentação do atual estado da arte brasileiro, 
investir numa sistematização crítica e que tenha os olhos voltados para o direito internacional e estrangeiro, de modo a evitar uma compreensão insulada e inadequada (e mesmo inapta) do problema que possa dar conta - a despeito das conhecidas e relevantes limitações - de alguns dentre os inúmeros desafios que a proteção da dignidade da pessoa humana e dos direitos de personalidade suscitam na era digital.

\section{0 problema do reconhecimento do direito ao esquecimento na condição de direito fundamental}

Embora os argumentos esgrimidos em prol do reconhecimento de um direito ao esquecimento sejam em boa parte já compartilhados por diversas ordens jurídicas e mesmo, em grande medida, aplicáveis às já convencionais hipóteses de embate entre a liberdade de expressão e de informação e a proteção da dignidade da pessoa humana e dos direitos de personalidade e ao ambiente digital, não se poderá aqui desconsiderar algumas peculiaridades no que concerne ao último.

Com efeito, na internet, como já em parte adiantado, embora em causa, de modo geral, os mesmos valores e direitos fundamentais, o contexto e suas peculiaridades têm ensejado problemas e desafios de grande complexidade - para o ora proposto, de natureza técnica e jurídica, de particularmente difícil equacionamento e solução. Em caráter ilustrativo, basta aqui referir a difusão do acesso à internet, a quase instantaneidade do fluxo de informações e de sua repercussão em grande escala, inclusive em nível global, e a dificuldade de estabelecer uma regulação adequada ou de, com efetividade, fazer valer o discurso dos direitos fundamentais em tal contexto.

Tais circunstâncias ensejam, também, a criação de novos mecanismos para a proteção da dignidade humana e dos direitos de personalidade por um lado (em si o objeto do direito ao esquecimento) e, por outro, dos princípios do estado de direito, da democracia e das correlatas liberdades comunicativas, apenas para mencionar as mais relevantes para o presente estudo.

Com isso, já se aproxima do problema da assim chamada fundamentalidade em sentido material do direito ao esquecimento.

Convém notar, em sede preliminar, que a exemplo do que ocorreu com o reconhecimento de um direito ao esquecimento na União Europeia ${ }^{9}$ e em diversos países europeus, como é o caso, entre outros, da Alemanha (WEISMANTEL, 2017), Espanha (CARO, 2015), França (DECHENAUD, 2015) e Itália (MARTINELLI, 2017), e mesmo em outros continentes, como no caso dos EUA (apesar das fortes objeções quanto ao reconhecimento de tal direito) (MAYER-SCHÖNBERGER, 2011; KELLY; SATOLA, 2017), também no Brasil tal conceito legal não se encontra explicitado no texto constitucional.

\footnotetext{
9 Aqui reportamo-nos às referências já feitas ao novo Regulamento de Proteção de Dados da União Europeia e ao caso Google vs. Agência Espanhola de Proteção de Dados e Mario Costeja, julgado pelo TJUE.
} 
A despeito disso, a doutrina e a jurisprudência brasileiras têm passado a reconhecer, em especial a partir de 2013, um direito ao esquecimento, atribuindo-lhe inclusive a condição de um direito fundamental, muito embora a existência de posições contrárias (SARMENTO, 2016, p. 190232). Ademais, não se verifica um consenso em relação a diversos pontos ligados ao tema, em especial no que diz respeito ao alcance, conteúdo, limites e critérios de aplicação. ${ }^{10}$

Ainda nesse contexto introdutório, é essencial que se leve em conta que o direito ao esquecimento assume - ao menos de acordo com a doutrina brasileira dominante - a dupla condição de um direito fundamental em sentido material e formal. Isso significa que, no tocante à dimensão material, o direito ao esquecimento deve encontrar fundamento em determinados valores e princípios superiores (além de guardar relação direta com outros direitos humanos e fundamentais), de modo a ser reconhecido e protegido como um direito fundamental (FERREIRA NETO, 2016, p. 278-323).

$\mathrm{Na}$ sua condição de direito fundamental em sentido formal, o direito ao esquecimento goza do regime jurídico qualificado dos direitos e garantias fundamentais, designadamente - no caso brasileiro - o da aplicabilidade imediata das normas que os consagram e a vinculação direta dos órgãos estatais (e mesmo, em certa medida, dos atores privados), bem como a sua proteção reforçada em face de intervenções restritivas por parte dos atores estatais e mesmo na esfera das relações entre particulares (SARLET, 2015). Como isso, manifesta-se no caso do direito ao esquecimento, em especial, no que diz respeito ao seu conteúdo e alcance, os quais serão objeto de atenção mais adiante.

$\mathrm{Na}$ perspectiva da sua justificação constitucional e tal como o demostra a experiência germânica, o reconhecimento do direito ao esquecimento radica na dignidade da pessoa humana, no direito ao livre desenvolvimento da personalidade e nos direitos especiais de personalidade, como é o caso dos direitos à vida privada, honra e imagem e do direito à autodeterminação informativa (BUCHHOLZ, 2015, p. 127 e ss.).

Para o caso do Brasil, contudo, é preciso relembrar que inexiste uma expressa previsão no texto constitucional de uma cláusula geral de proteção da personalidade ou mesmo um direito ao livre desenvolvimento da personalidade, que tem sido, de acordo com um entendimento já pacificado (pelo menos de modo absolutamente dominante) na literatura jurídica nacional, deduzido do (e associado ao) princípio da dignidade da pessoa humana (TEPEDINO, 1999, p. 44 e ss.; ANDRADE, 2006, p. 101; MORAES, 2003, p. 117 e ss.; SCHREIBER, 2014, p. 7 e ss.).

Nessa senda, a conexão do direito ao esquecimento com a dignidade da pessoa humana e o direito geral de personalidade, no sentido de um direito ao livre desenvolvimento da personalidade, pode ser justificada, numa primeira aproximação, com o fato de que a capacidade e a possibilidade de esquecimento e a necessidade de seu reconhecimento e proteção na esfera jurídica representam condição necessária para exercer também o que se designou um direito a se reinventar ${ }^{11}$ ou a

\footnotetext{
10 Limitando-nos aqui a referir as principais obras monográficas (livros) dedicadas especialmente ao tema no Brasil, v. Martinez (2014), Maldonado (2016), Carello (2016), Consalter (2017) e Branco (2007).

11 V. nesse sentido Solove (2011, p. 15-30).
} 
um recomeço, ou seja, a possibilidade de reformatar (reconstruir) a trajetória existencial pessoal (individual) e social, livre de determinadas amarras provocadas pela confrontação direta e permanente no tempo com aspectos relativos à memória (passado) (DIESTERHÖFT, 2014 p. 150). ${ }^{12}$

Dito de outro modo, a possibilidade de esquecer, mas também - e nisso a necessidade de reconhecimento e proteção em face do estado e de terceiros no plano social ampliado - poder ser "esquecido" e não sofrer permanentemente e de modo indeterminado as repercussões negativas associadas a fatos (aqui em sentido amplo) do passado é algo essencial não apenas para uma vida saudável pessoal - do ponto de vista físico e psíquico - mas para uma integração social do indivíduo.

Não é à toa que no tocante ao reconhecimento de um direito ao esquecimento é de se levar a sério a lembrança de Catarina Santos Botelho, no sentido de que, a partir das lições da neurologia, sabe-se que uma das principais funções do cérebro é a de esquecer tudo aquilo que é supérfluo e filtrar conteúdos que prejudicam emocionalmente os indivíduos (BOTELHO, 2017, p. 52).

Nessa perspectiva, trata-se também, e em certo sentido, da necessidade de assegurar uma determinada possibilidade de autogovernar a própria memória e de poder reagir de algum modo à "implacável memória coletiva da internet", além de impedir que as pessoas fiquem prisioneiras de "um passado destinado a não passar" (RODOTÀ, 2014, p. 41-42).

Tal afirmação indica, por sua vez, que o direito ao esquecimento assume uma dimensão que vai além da individual, porquanto já se demonstrou que o esquecimento, aqui com destaque para a internet, consiste num processo social que carece de descrição e compreensão independentemente do esquecimento por parte das pessoas individualmente consideradas e que guarda relação com o que se costuma designar de uma "memória coletiva" (ALBERS; SCHIMKE, 2018). ${ }^{13}$

Isso significa, em apertada síntese, que a tese de que a internet não esquece não deve ser entendida de um modo fechado e absoluto, pois, entre outros fatores, há sempre uma interação dinâmica entre lembrar e esquecer, já que a escolha de determinada informação para sua divulgação implica que toda uma gama de outras informações, que não foram escolhidas, sejam esquecidas para os atuais processos de comunicação, de modo que em princípio, e de uma perspectiva abstrata, se esquece tanto quanto se lembra (ALBERS; SCHIMKE, 2018).

Nesse contexto - dada a relevância de tal aspecto para o direito ao esquecimento - é de se lembrar, ainda, que na internet a informação (portanto, também a "memória") - pode ser perdida de diversas formas, quais sejam, pelo fato de não ter sido armazenada, pela danificação do seu suporte técnico ou por não ser acessível pelos meios disponíveis (ESPOSITO, 2017, p. 1-11). Isso, por evidente, deve ser considerado quando da definição do conteúdo, limites e eficácia do direito ao esquecimento.

\footnotetext{
12 Note-se, contudo, que Diesterhöft (2014) refere-se a uma dimensão mais restrita do que designa de um direito ao recomeço, pois fala especificamente num recomeço "medial", com ênfase no ambiente digital, o que, na perspectiva aqui adotada, soa demasiadamente limitado.

13 Destaque-se que as autoras fazem referência a diferentes tipos de memória, a individual, a social, a cultural e a política, o que não será objeto de aprofundamento no presente texto.
} 
Por outro lado, verifica-se que mediante o reconhecimento de um direito ao esquecimento não se trata de atribuir um direito subjetivo no sentido de poder obrigar alguém, do ponto de vista individual, a esquecer algo, o que resulta tecnicamente impossível salvo mediante coercitiva imposição de determinados procedimentos médicos, o que, além de manifestamente ilegítimo do ponto de vista jurídico (e ético), de qualquer modo não teria o condão de influir na esfera da memória coletiva.

Por isso - como destacado anteriormente - é que se fala de um processo de esquecimento social, que se reflete no plano individual, mas que se realiza pela eventual supressão de determinadas informações e em dificultar o acesso a elas. Tais aspectos, por sua vez, guardam relação direta com o problema do conteúdo, dos limites e dos modos de efetivação do direito ao esquecimento.

Assim, em apertada síntese, é possível sustentar que o direito ao esquecimento, na perspectiva da ordem constitucional brasileira, constitui um direito fundamental de natureza implícita, manifestação (e mesmo exigência) da dignidade da pessoa humana e do direito ao livre desenvolvimento da personalidade, guardando relação, ainda, com diversos direitos de personalidade consagrados - de modo explícito e implícito - pela CF, como os direitos à privacidade, intimidade, honra e imagem, mas também os direitos à autodeterminação informativa, ao nome e o direito à identidade pessoal, todos já reconhecidos pelo STF (BOTELHO, 2017, p. 61 e ss.).

À vista dos elementos colacionados, é possível afirmar que as razões dos que refutam a possibilidade de reconhecer um direito fundamental ao esquecimento na ordem constitucional brasileira são frágeis. Em especial, não convence o argumento de que tal direito não poderia ser extraído nem pela via da interpretação, já que os direitos de personalidade (no caso, a privacidade, a intimidade, a honra e a imagem) não abarcam o esquecimento de fatos que dizem respeito ao interesse público, ainda mais em face da posição prioritária da liberdade de expressão e informação (SARMENTO, 2016, p. 204 e ss.).

Tal linha argumentativa, todavia, não convence, porquanto a objeção diz respeito ao conteúdo e alcance de um direito ao esquecimento - mais precisamente, dos critérios para o seu reconhecimento e aplicação - do que com a circunstância de que em princípio os direitos de personalidade não incluem uma proteção contra evidentes abusos no exercício da liberdade de expressão e de informação, que, mesmo onde se lhes atribui uma posição preferencial, não assume feições absolutas. Aliás, chama a atenção que mesmo quem formulou a objeção referida acaba por admitir um campo de aplicação - embora em caráter excepcional - para um direito ao esquecimento quando se tratar de informações destituídas de qualquer interesse público (BRANCO, 2007, p. 143).

Mas, antes de avançar-se com a apresentação e análise de casos emblemáticos julgados pelos Tribunais Superiores (destaque para o STJ), é o caso de lembrar que, para além de sua qualificação (constitucional) como direito fundamental, na legislação infraconstitucional também se registra a existência (inclusive bem antes da querela em torno do reconhecimento de um direito ao esquecimento) de regras que correspondem a algumas de suas manifestações específicas, ou então contribuem para a justificação da existência do direito ao esquecimento e para o estabelecimento de 
seus limites. Além disso, já existem diversas propostas legislativas tramitando no Congresso Nacional prevendo o reconhecimento expresso de um direito ao esquecimento e mesmo estabelecendo regras para a sua aplicação.

Em caráter aqui muito sumário, há que colacionar os artigos 135 do Código Penal, 748 do Código Processual Penal e 202 da Lei de Execuções finais, que, em linhas gerais, vedam que os antecedentes criminais de alguém sejam levados a público e possam ser utilizados apenas para uma nova investigação e/ou processo criminal.

No mesmo sentido, o assim chamado Estatuto da Criança e do Adolescente (Lei n. 8.069, de 13 de julho de 1990) contempla regras que podem ser utilizadas no reconhecimento de um direito ao esquecimento, promovendo a proteção da dignidade e direitos de personalidade das crianças (até 12 anos incompletos de idade) e adolescentes (12-18 anos). Assim, além da previsão do artigo 18 no sentido de que crianças e adolescentes não podem ser submetidos a qualquer tipo de tratamento desumano, violento, aterrorizante, vexatório ou constrangedor, o artigo 143 veda "a divulgação de atos judiciais, policiais e administrativos que digam respeito a crianças e adolescentes a que se atribua autoria de ato infracional." Soma-se a isso que de acordo com o parágrafo único do mesmo artigo que nenhuma notícia a respeito do fato poderá identificar a criança ou adolescente, vedandose fotografias, referências ao nome, apelido, filiação, parentesco, residência e, inclusive, iniciais do nome e sobrenome (BRASIL, 1990).

Na esfera cível, o Código de Defesa do Consumidor (Lei n. 8078/1990), em especial (mas não só) no seu artigo 43, contempla aspectos que dizem respeito também ao direito ao esquecimento e à livre autodeterminação informativa, pois dispõe que o consumidor deve ter livre acesso aos seus próprios dados informados em bancos de dados, fichários e arquivos, sendo-lhe assegurado $\left(\mathbb{S} 2^{\circ}\right)$ um direito de retificação. $\bigcirc$ consumidor poderá ainda requerer o cancelamento (exclusão) dos dados constantes nos cadastros negativos depois de transcorridos cinco anos do seu armazenamento.

Mas também o Código Civil Brasileiro (Lei n. 10.406, de 10 de janeiro de 2002), particularmente nos seus artigos 11, 12, bem como e em especial nos artigos 16 a 21, no capítulo referente aos direitos de personalidade, oferece fundamento para a proteção de aspectos ligados ao direito ao esquecimento. Ao passo que nos artigos 11 e 12 se encontram previstas regras gerais para a proteção dos direitos de personalidade, nos artigos 16 a 21 são consagradas normas que guardam relação, ainda que indireta, com aspectos importantes que dizem respeito também a um direito ao esquecimento, como é o caso do direito ao nome (prenome, sobrenome e mesmo ao pseudônimo) e sua proteção (artigos 16-19). Particularmente relevante para o caso do direito ao esquecimento é o artigo 21, no qual, em caráter mais geral, se dispõe que "a vida privada da pessoa natural é inviolável, e o juiz, a requerimento do interessado, adotará as providências necessárias para impedir ou fazer cessar ato contrário a esta norma", preceito normativo a ser manejado em sintonia tanto com o marco constitucional quanto com os demais dispositivos legais que dizem respeito ao tema. 
No caso do ambiente digital (ao qual podem ser também aplicados, mediante eventuais ressalvas e dadas as circunstâncias, o previsto nos diplomas legais anteriormente colacionados), o documento legislativo mais importante em vigor no Brasil é a assim chamada Lei do Marco Civil da Internet (Lei Federal n. 12.965, de 23 de abril de 2014), que estabeleceu um conjunto de princípios, bem como previu garantias, direitos e deveres para o uso da internet no Brasil. Tal diploma legal, mesmo não prevendo expressamente o direito ao esquecimento, contém importantes diretrizes e regras concretas que podem ser reconstruídas para fins de se reconhecer a necessidade de acolhimento dessa pretensão jurídica individual em determinados casos, conforme se vê dos seguintes dispositivos que, interpretados sistematicamente, reconduzem à conclusão que aponta para a existência do direito ao esquecimento no direito nacional, além de regular aspectos específicos relativos a tal direito fundamental, dando-lhe concretude ao menos parcial.

Nessa perspectiva, ao passo que o artigo $2^{\circ}$ da Lei estabelece que o "uso da internet no Brasil tem como fundamento o respeito à liberdade de expressão", razão pela qual a sua utilização deverá sempre garantir e efetivar "os direitos humanos, o desenvolvimento da personalidade e o exercício da cidadania em meios digitais", no artigo $7^{\circ}$ restou consagrada uma espécie de catálogo de direitos e garantias dos usuários da internet, que também envolvem a proteção dos dados pessoais, da privacidade e a autodeterminação informativa, inclusive reproduzindo dispositivos constitucionais, ademais de lhes dar concretude, regulando diversos aspectos que lhes são correlatos, no ambiente da internet (BRASIL, 2014).

De acordo com o artigo $7^{\circ}$, o acesso à internet é essencial ao exercício da cidadania, e ao usuário são assegurados, dentre outros, os seguintes direitos:

I - inviolabilidade da intimidade e da vida privada, sua proteção e indenização pelo dano material ou moral decorrente de sua violação; [...] VII - não fornecimento a terceiros de seus dados pessoais, inclusive registros de conexão, e de acesso a aplicações de internet, salvo mediante consentimento livre, expresso e informado ou nas hipóteses previstas em lei; [...] IX - consentimento expresso sobre coleta, uso, armazenamento e tratamento de dados pessoais, que deverá ocorrer de forma destacada das demais cláusulas contratuais; X - exclusão definitiva dos dados pessoais que tiver fornecido a determinada aplicação de internet, a seu requerimento, ao término da relação entre as partes, ressalvadas as hipóteses de guarda obrigatória de registros previstas nesta Lei; [...] XIII - aplicação das normas de proteção e defesa do consumidor nas relações de consumo realizadas na internet. (BRASIL, 2014).

Soma-se a isso a previsão (artigo $19 \$ 4^{\circ}$ ) da possibilidade de concessão de tutela antecipada pelo Juiz quando existir prova inequívoca do fato e considerando o interesse da coletividade na disponibilização do conteúdo na internet. De todo modo, é certo que no referido artigo 19 não se encontra previsto expressamente um direito à desvinculação de conteúdos na internet, mas apenas a responsabilização dos provedores de aplicação por danos gerados por conteúdo de terceiros (GONÇALVES, 2016, p. 88). 
Já em conformidade com o artigo 21, os provedores poderão ser subsidiariamente responsabilizados caso disponibilizem informações mantidas por terceiros - no caso, vídeos ou outros materiais contendo cenas de nudez ou de atos sexuais de caráter privado - sem que os afetados pelos conteúdos tornados públicos tenham dado o seu consentimento expresso, ou então quanto os provedores não atendam aos termos de notificação extrajudicial enviada pelo ofendido.

Todavia, embora o Marco Civil da Internet preveja um direito à exclusão de conteúdos tidos como prejudiciais e/ou ilícitos, é necessário ressaltar que o direito ao esquecimento, pelo menos na forma em que é compreendido e como foi reconhecido na decisão Google do TJUE (embora esta não tenha feito expressa menção a tal direito), não se limita a tais aspectos, pois abarca (e mesmo possivelmente se centra) um direito à desindexação junto aos mecanismos de busca, devendo, ademais, atender a determinados critérios, que serão mais adiante abordados.

Mas, se a legislação em vigor não contempla expressamente e não dá conta de todos os aspectos que envolvem o direito ao esquecimento, existem atualmente vários projetos de lei que preveem e regulamentam um direito ao esquecimento, mas que ainda se encontram em fase de tramitação no Congresso Nacional. Todos os projetos guardam relação direta com o ambiente da internet, muito embora não de modo exclusivo em todos os casos. ${ }^{14}$

Em face disso, tais projetos (bastaria um) - caso aprovados - poderão ter grande repercussão e consequências práticas, além de suscitarem diversos problemas jurídicos, inclusive na perspectiva constitucional que resulta aqui já praticamente evidente. Assim, eles serão objeto de atenção também no contexto da análise geral e crítica a ser efetuada mais adiante.

\section{0 direito ao "esquecimento" na internet e seu reconhecimento e proteção no âmbito dos tribunais superiores (STJ e STF)}

Muito embora o objeto do presente texto seja o direito ao esquecimento no domínio digital, os casos nos quais tal direito foi reconhecido e assegurado não dizem respeito à internet. Por tal razão - e também em virtude dos argumentos e critérios manejados em tais decisões - imprescindível que, num primeiro momento, sejam eles aqui sumariamente apresentados, sublinhando-se que aqui se restringirá a análise aos julgamentos em matéria cível a aos que se entende como mais relevantes, em virtude de sua particular importância para uma avaliação geral e crítica do tratamento do tema no Brasil. Note-se, ainda, que à exceção de julgado do STF onde foi reconhecida a Repercussão Geral da matéria, todos os casos foram decididos pelo STJ.

$\overline{14}$ Segue a relação dos projetos de lei: PL n. 2712/2015, de autoria do Deputado Jefferson Campos, PL n. 1676/2015, de autoria do Deputado Veneziano Vital do Rêgo, e PL n. 8.443/2017, de autoria do Deputado Luiz Lauro Filho. 


\subsection{Principais decisões envolvendo um direito ao esquecimento fora dos domínios da internet}

Os dois primeiros casos em que esteve em causa um direito ao esquecimento (todavia, em sentido amplo, visto que não se tratava da proibição de veiculação de determinados fatos ou do apagamento de dados ou da desindexação de determinados links dos mecanismos de busca na internet), ambos julgados pelo STJ, foram apreciados nos Recursos Especiais n. 1335153/RJ e n. 1334097/RJ (2013). Nesses dois casos, julgados pela $4^{a}$ Turma da Corte Superior no mesmo dia, foram estabelecidos alguns parâmetros para o reconhecimento e respectivas consequências jurídicas de um direito ao esquecimento no Brasil; foram, contudo, alcançadas conclusões opostas, visto que em um dos casos foi assegurada a proteção de tal direito, é ao passo que no outro foi dada prevalência à liberdade de informação e comunicação. Tal discrepância não necessariamente se revela contraditória, mas desde logo aponta para o fato de que, a exemplo de outros casos em que se verifica uma colisão de direitos, é necessária uma análise das peculiaridades de cada caso, do peso dos direitos envolvidos, bem como do impacto resultante de sua maior ou menor proteção, tudo mediante uma operação de ponderação destinada a estabelecer um equilíbrio e uma solução adequada do ponto de vista jurídico.

No primeiro caso, conhecido como caso Aída Curi (Resp. n. 1.335.153/RJ), os familiares de Aida Curi, vítima de assassinato cometido em 1958, que havia adquirido ampla notoriedade à época em que praticado, queriam impedir que programa televisivo veiculado pela TV Globo (Programa Linha Direta) reproduzisse e reconstituísse, ainda que na condição de documentário, décadas depois, esse mesmo episódio traumático, fazendo com que "antigas feridas já superadas" fossem reabertas em público. Defenderam os autores, portanto, que deveria ser acolhida a pretensão de se declarar, no caso, "seu direito ao esquecimento, de não ter revivida, contra a vontade deles, a dor antes experimentada por ocasião da morte de Aida Curi, assim também pela publicidade conferida ao caso décadas passadas." Além disso, pleitearam indenização por danos imateriais.

Analisando as particularidades do caso, o Ministro Relator, Luís Felipe Salomão, entendeu que:

a) as vítimas de crimes e seus familiares, em tese, também podem ser titulares do direito ao esquecimento, na medida em que não podem ser obrigadas a se submeter desnecessariamente a "lembranças de fatos passados que lhes causaram inesquecíveis feridas", ademais da circunstância de que injusta a proteção do eventual ofensor, por conta de seu direito à ressocialização, deixando a vítima e seus familiares à mercê da sua pública e permanente exposição;

b) a resolução adequada do caso exige a ponderação da possível historicidade do fato narrado com a proteção à intimidade e privacidade dos ofendidos; 
c) no caso, o crime entrou para o domínio público, tornando-se, de tal sorte, um fato de natureza histórica, não podendo ser transformado em fato inacessível à imprensa e à coletividade. Além disso, devido à ampla difusão dada ao fato na época dos acontecimentos, inclusive da investigação e julgamentos, bem como a conexão direta com o nome da vítima, seria impraticável "retratar o caso Aída Curi, sem Aída Curi;

d) diante da situação concreta, seria desproporcional a restrição da liberdade de imprensa, se comparada ao desconforto gerado pela lembrança dos fatos por parte dos familiares da vítima, em particular considerando o largo lapso temporal transcorrido desde a data dos fatos, que tem o condão de esmaecer, ainda que não afastar por completo, a dor e o abalo causado pelos fatos e sua divulgação.

No segundo julgado, conhecido como caso Chacina da Candelária (RESP n. 1.334.097/ RJ), igualmente se pretendeu evitar veiculação de programa televisivo (Linha Direta), ademais de pleitear indenização por danos imateriais por parte da Rede Globo de Televisão. O autor da demanda originária, também aforada contra a empresa Globo Comunicações e Participações, alegava a ausência de contemporaneidade dos fatos e que a reabertura de "antigas feridas", que já haviam por ele sido superadas, teria reascendido a desconfiança da sociedade no que diz respeito à sua índole, pugnando pelo reconhecimento de seu direito de ser esquecido, ou seja, não ser lembrado contra a sua vontade, em decorrência de fatos criminosos pelos quais havia sido indiciado e processado, mas pelos quais restou absolvido.

Diferentemente do caso anterior, aqui o mesmo Ministro, Luís Felipe Salomão, igualmente Relator do feito, deu ganho de caso ao autor da demanda (recorrido), depois de estabelecer alguns pressupostos, argumentando que:

a) mesmo sendo os crimes reportados famosos e de contornos históricos e não obstante fosse a reportagem jornalística fiel à realidade, deveria prevalecer a proteção à intimidade e privacidade dos condenados e dos absolvidos, como no caso do recorrido, uma vez que a "vida útil da informação criminal" já havia alcançado o seu termo final;

b) o reconhecimento de um direito ao esquecimento expressa "uma evolução cultural da sociedade, confere concretude a um ordenamento jurídico, que, entre a memória que é a conexão com o passado - e a esperança - que é o vínculo com o presente - fez clara opção pela segunda", cuidando-se, no caso do direito ao esquecimento, de "um direito à esperança, em absoluta sintonia com a presunção legal e constitucional de regenerabilidade da pessoa humana";

c) a historicidade inconteste dos fatos aos quais se refere o programa televisivo deve ser examinada em concreto, afirmando-se o interesse público e social, desde que, contudo, a identificação pessoal dos envolvidos seja indispensável. No caso julgado, 
muito embora se trate de um acontecimento histórico e um símbolo da precariedade da proteção estatal das crianças e adolescentes, o documentário poderia ter retratado os fatos de forma correta sem identificar, pelo nome ou pela imagem, os envolvidos, em particular a pessoa do recorrido;

d) além disso, permitir a divulgação do nome e imagem do recorrido, ainda que absolvido (que mesmo assim teria reforçada a sua imagem de acusado e envolvido), seria o mesmo que permitir uma segunda violação de sua dignidade, uma vez que o próprio fato e sua ampla divulgação, incluindo o nome do recorrente como suspeito, assim como inquérito policial, já representaram na época uma vergonha nacional.

À vista dos argumentos colacionados, percebe-se que, nesse segundo caso, prevaleceu o critério do esgotamento da função sancionatória e da necessidade de reabilitação e reinserção social dos condenados e absolvidos, o que superaria o peso argumentativo não apenas da, no caso, evidente historicidade dos fatos que seriam objeto da reportagem jornalística, mas também da liberdade de expressão inerente à atividade da imprensa.

Outro caso que merece ser destacado é o assim chamado caso Brilhante Ustra (Resp. 1434498, julgado em 05 de fevereiro de 2015, relatora Ministra Nancy Andrighi e voto-vista do Ministro Paulo Sanseverino), no qual um militar reformado (Cel. Brilhante Ustra) invocou o direito ao esquecimento em face de demanda que pretendia ver declarada a sua responsabilidade por atos atentatórios aos direitos humanos dos demandantes (vítimas de tortura), argumentando que estaria também resguardado pela legislação da anistia. Embora a Relatora tenha acolhido tais argumentos, os demais Ministros que participaram do julgamento entenderam que a anistia não abarca o reconhecimento, na esfera cível (ainda mais em ação de caráter declaratório) de atos praticados ao tempo da ditatura militar, além de ser o caso de se dar prevalência também - numa perspectiva coletiva - a um direito à memória e à verdade.

Particularmente relevante para a discussão em torno do conteúdo e alcance de um direito ao esquecimento no Brasil é o fato de que o STF (a partir do caso Aída Curi) reconheceu a Repercussão Geral da discussão (SCHREIBER, 2017a), uma vez que seria passível de apreciação em sede de Recurso Extraordinário a alegação de que

o direito ao esquecimento é um atributo indissociável da garantia da dignidade humana, com ela se confundindo, e que a liberdade de expressão não tem caráter absoluto, não podendo se sobrepor às garantias individuais, notadamente à inviolabilidade da personalidade, da honra, da dignidade, da vida privada e da intimidade da pessoa humana. (SCHREIBER, 2017).

No decurso do processo, o Relator, Ministro Dias Toffoli, convocou Audiência Pública, realizada em 12 de junho de 2017, na qual foram ouvidos representantes de diversas entidades públicas e privadas, inclusive vinculadas ao domínio digital (como foi o caso do Google e do Yahoo), 
de modo que é possível arriscar prognóstico no sentido de que a decisão do STF quando julgar o mérito da questão propriamente dita provavelmente adentrará a repercussão de um direito ao esquecimento na internet.

Em apertada síntese é possível afirmar que na audiência pública se fizeram representar três correntes de opinião. A primeira, formada em especial pelos representantes da mídia, sustentou a prevalência da liberdade de informação e expressão e a impossibilidade de se reconhecer um direito ao esquecimento. A segunda corrente advogou a prevalência dos direitos da personalidade e, portanto, do direito ao esquecimento, quando se tratar de abuso na liberdade de expressão e, em geral, de informações e manifestações ofensivas aos direitos de personalidade. Já pelos representantes da terceira linha de entendimento, designada de intermediária, foi arguido que a prevalência, ou não, dos direitos de personalidade ou da liberdade de expressão e de informação, seja analisada caso a caso, mediante cuidadosa ponderação (SCHREIBER, 2017a). De todo modo, enquanto o julgamento definitivo é aguardado, não é possível afirmar qual posição sairá vencedora no STF.

\subsection{0 direito ao esquecimento na internet}

No que diz com o reconhecimento de um direito ao esquecimento na internet, não se registra, por ora, julgado do STF sobre o tema (embora o julgamento da Repercussão Geral referida deva repercutir também na seara digital), mas limita-se aqui às principais decisões do STJ proferidas até a data da conclusão do presente texto.

Nesse contexto, importa destacar que o direito ao esquecimento na internet (tomado em sentido amplo) não se limita à responsabilidade dos provedores de pesquisa e a um direito à desindexação. De fato, levando em conta o objeto do direito ao apagamento de dados estabelecido na Lei do Marco Civil da Internet, o direito ao esquecimento, pelo menos no caso brasileiro, no qual inexiste regra específica prevendo a desindexação pelos provedores de pesquisa, assume relevância também no que se refere aos provedores de conteúdo, em especial nas assim chamadas mídias sociais, compartilhadores de vídeos e fotografias, etc.

Todavia, muito embora a frequência dos casos judiciais envolvendo responsabilidade de provedores de conteúdo em razão do não apagamento de manifestações de toda natureza tidas como inverídicas, incorretas, ofensivas aos direitos de personalidade e mesmo tipificadas criminalmente, chama a atenção, pelo menos no caso das decisões do STJ sobre a matéria, que não se tem aqui invocado diretamente um direito ao esquecimento. Por esse motivo, não se irá aqui centrar atenção nesses julgados, mas, sim, aos que fizeram referência a um direito ao esquecimento e se dedicaram à sua compreensão e aplicação. 
De todo modo, apenas para não deixar completamente intocado o ponto, é de se salientar que a jurisprudência dominante e consolidada do STJ, ${ }^{15}$ pode ser resumida nos seguintes termos:

a) os provedores de aplicação e conteúdo, incluindo as redes sociais, não respondem objetivamente pela inserção no site, por terceiros, de informações ilegais;

b) não podem ser obrigados a exercer um controle prévio do conteúdo das informações postadas pelos usuários;

c) contudo, no momento em que tiverem inequívoca ciência da sua existência devem removê-los imediatamente sob pena de responsabilização pelos danos causados;

d) devem manter um sistema minimamente eficaz que permita a identificação dos seus usuários, cuja efetividade será verificada caso a caso (isso para dar cumprimento à vedação do anonimato estabelecida expressamente pela CF ao assegurar a liberdade de expressão);

e) a sua responsabilidade é subjetiva, sendo solidária com o autor da postagem do conteúdo ilícito, quando ao tomar conhecimento do caráter lesivo de determinado conteúdo não toma as devidas providências para a sua remoção.

Além disso, exige o STJ a indicação precisa pelo autor da ação do localizador URL do conteúdo tido como ilícito como condição para a obtenção da ordem judicial de sua remoção, o que além de ser um critério para o estabelecimento da responsabilidade, evitando ordens vagas e imprecisas, contribui para assegurar um controle efetivo do cumprimento da decisão. Tal exigência corresponde ao previsto pelo Marco Civil da Internet, no sentido de que o conteúdo impugnado deve ser clara e especificamente identificado (BRASIL, 2017).

Mas particularmente importantes para o presente trabalho são as decisões do STJ que dizem respeito à responsabilidade dos provedores de pesquisa e ao assim chamado direito à desindexação, como ocorreu no paradigmático (mas nem por isso menos polêmico) caso Google vs. Agência Espanhola de Proteção de Dados e Mario Costeja.

Note-se, ainda nessa quadra, que o STJ vinha, em regra, refutando a responsabilidade dos provedores de pesquisa em relação a conteúdos postados por terceiros e tornados facilmente disponíveis mediante mecanismos de buscas, afastando, portando, diversos pedidos no sentido da desindexação de links de modo a impedir, ou pelo menos dificultar sobremaneira, o acesso pelos usuários da internet a determinadas informações.

Muito embora, em julgado recente (Resp. 1.660168/RJ, 08.05.18), a $3^{\text {a }}$ Turma do STJ tenha sinalizado uma possível guinada quanto à responsabilidade dos provedores de pesquisas, deferindo um pedido de desindexação e impondo a instalação de filtros nos mecanismos de buscas, importa

\footnotetext{
15 Nesse sentido, v. Brasil (2017).
} 
antes de mais nada apresentar alguns dos casos anteriores. Isso se revela de utilidade, seja pelo fato de que nas respectivas decisões foram invocados importantes argumentos em sentido contrário (à responsabilidade dos provedores de pesquisa), seja por terem sido ventilados critérios para a decisão a respeito do mérito propriamente dito de um direito ao esquecimento e dos seus limites.

O primeiro caso que chegou ao STJ ficou conhecido como o caso Xuxa, objeto de julgamento no Recurso Especial 1.316.921, relatado pela Ministra Nancy Andrighi, tendo sido julgado em 26 de junho de 2012. Cuidava-se de ação movida por Maria da Graça Xuxa Meneghel, então ainda apresentadora de programas infantis e infanto-juvenis, contra a empresa Google Brasil Internet Ltda., objetivando a supressão dos mecanismos de busca de todo e qualquer resultado relativo à busca com base na expressão "xuxa pedófila" ou qualquer outra expressão que associasse o nome da autora a qualquer tipo de prática criminosa.

O STJ, contudo, ao apreciar a irresignação da demandada (Google Search), acabou adentrando o problema específico relativo a um direito ao esquecimento, dando, contudo, integral provimento ao recurso. Naquilo que importa ao estudo, seguem, em síntese, as razões que fundamentaram a decisão, que serão objeto de avaliação crítica mais adiante:

a) ao Google Search, cuja atividade se limita a de operar como mecanismo de busca e provedor de pesquisa, não se aplica o disposto no artigo 14 do Código de Defesa do Consumidor, pois, ao contrário do que se verifica com os provedores de conteúdo, o Google Search se limita a indexar termos e "indicar links onde podem ser encontrados os termos ou expressões de busca fornecidos pelo próprio usuário". Por tal razão também não há que falar, nesse tipo de atividade, de serviço defeituoso;

b) como a atividade do provedor de pesquisa é realizada num ambiente virtual, que permite o acesso público e irrestrito, ainda que não existissem mecanismos de busca como os oferecidos pelo Google Search, os conteúdos considerados de cunho ilícito seguiriam circulando e sendo disponibilizados na internet;

c) que, dado o caráter subjetivo e arbitrário que envolve a decisão de retirar, ou não, links, resultados e páginas que veiculem conteúdos ofensivos (ilícitos) na internet, não se pode delegar aos provedores de pesquisa tal margem de discricionariedade;

d) quem se considera afetado pela divulgação de alguma informação (conteúdo) na internet, deveria voltar-se contra os responsáveis diretos pela inserção de tais dados na rede mundial de computadores, e não contra os provedores de pesquisa, que então sequer teriam como dar acesso aos conteúdos tidos como ofensivos. Assim, o único modo de se excluir o conteúdo tido como ilícito (ofensivo) reside na identificação da respectiva URL, especificando-se o endereço responsável pelo seu armazenamento na rede mundial de computadores; 
e) o embate entre a liberdade de expressão e comunicação, em especial na sua dimensão coletiva, deve prevalecer sobre os interesses individuais, atribuindo-se maior peso ao direito à informação.

Uma segunda decisão relevante foi tomada pelo STJ no Recurso Especial 1407271/ SP, julgado em 21 de novembro de 2013 (BRASIL, 2013). Aqui se tratava de ação intentada por empregada demitida de empresa depois de ter sido encontrado, no seu e-mail corporativo, vídeo contendo cenas íntimas gravadas nas dependências da empresa, vídeo que foi postado na internet, disponibilizado no Orkut e acessível pelos mecanismos de busca do Google. A autora da ação pretendia obter a desvinculação de todas as URLs prejudiciais do Google, a remoção do site do Orkut de qualquer menção ao seu nome e o fornecimento de dados de todos os responsáveis pela publicação de mensagens que lhe eram ofensivas.

Importa sublinhar que já na decisão em primeira Instância, entendeu-se que não haveria como remover todas as páginas postando o vídeo, convertendo-se a obrigação em perdas e danos, mediante o arbitramento de uma indenização. No julgamento pelo STJ, no qual o pedido da autora não foi acolhido, além da reiteração de argumentos manejados no caso anterior, foi realizada ponderação em favor da liberdade de informação, argumentando que o pedido da autora seria juridicamente impossível pelo fato de ser desarrazoado no caso concreto. Além disso, foi referido o comportamento da autora como sendo ingênuo e displicente por ter mantido no seu correio eletrônico vídeos com imagens íntimas.

O último dos casos (negando a responsabilidade dos provedores de pesquisa) a ser aqui colacionado foi julgado em novembro de 2016 (Resp. n. 1.593.873-SP) (BRASIL, 2016). Tratavase de uma demanda aforada contra o Google Brasil Internet (recorrente) com o intento de excluir em caráter definitivo dos mecanismos de busca todos os links dando acesso a imagens íntimas da autora. Aqui também foram reiterados os principais argumentos esgrimidos nas decisões anteriores. Importa destacar, todavia, que no caso aqui apresentado (e diferentemente dos demais) a maioria dos Ministros entendeu que no Brasil inexiste previsão legal específica impondo tal responsabilidade, inaplicável também o decidido pelo Tribunal de Justiça da União Europeia no caso Google vs. Agência Espanhola de Proteção de Dados e Mario Costeja.

A partir dos casos apresentados, é possível verificar, em caráter de síntese e para empreender uma análise global e crítica, o seguinte cenário, no que concerne ao entendimento até a pouco dominante no STJ em relação ao direito ao esquecimento na internet, no que diz respeito aos mecanismos de busca e um direito à desindexação.

Resumindo aqui os diversos argumentos (e critérios) manejados nas decisões apresentadas, o STJ vinha entendendo que os provedores de pesquisas: 
a) não respondem pelo conteúdo dos resultados das buscas levadas a efeito pelos respectivos usuários;

b) não podem ser obrigados a eliminar resultados derivados das buscas com base em determinado termo ou nome;

c) não podem ser obrigados a exercer um controle prévio do conteúdo dos resultados das buscas feitas por cada usuário;

d) a responsabilidade, portanto, há de recair não sobre o provedor de pesquisa, mas, sim, naquele site que armazena a informação e que é acessado via mecanismo de busca;

e) o provedor de pesquisas não pode atuar como uma espécie de censor digital;

f) no embate entre os direitos de personalidade e a liberdade de expressão e informação prevalece em regra a última;

g) o comportamento da pessoa afetada pela informação deve ser avaliado em concreto e ser utilizado como critério para a ponderação;

h) apenas em caso de descumprimento de ordem judicial se verifica a responsabilidade também do provedor de pesquisas, seja quanto à cominação de multa, seja em termos de responsabilidade civil por eventuais danos causados;

i) a ausência de previsão legal expressa estabelecendo a obrigação de desindexação e responsabilização não pode ser suprida judicialmente.

Mas, como já adiantado, com o julgamento do RESP n. 1.660168/RJ, de 08 de maio de 2018, o STJ acabou (por maioria) rompendo com a orientação que prevalecia até então e deu guarida a um pedido de desindexação, reconhecendo a responsabilidade dos provedores de pesquisa. Para compreender melhor a questão e mesmo verificar se todos os argumentos invocados nas decisões anteriores foram refutados e, em especial, identificar os critérios aplicados para justificar a procedência do pleito com base no direito ao esquecimento, segue uma breve descrição do caso e da decisão, inclusive das suas razões subjacentes. ${ }^{16}$

No que toca ao caso propriamente dito, tratava-se de julgamento de Recurso Especial interposto pelas empresas Google Brasil Internet Ltda., Yahoo do Brasil Internet Ltda. e Microsoft Informática Limitada em relação a julgamento em sede de apelação julgada pelo Tribunal de Justiça do Rio de Janeiro, que, por sua vez, havia reformado sentença proferida na primeira instância que não reconhecera o direito ao esquecimento da demandante, uma integrante do Ministério Público estadual, no sentido de determinar aos então requeridos que implantassem filtro por palavra-chave com o escopo de evitar a associação do nome da autora da ação a notícias envolvendo suposta fraude praticada quando de concurso público para a Magistratura Estadual, ocorrido em 2007. Note-se que

$\overline{16}$ Note-se, contudo, que quando do encerramento para envio à editora do manuscrito do presente texto, o Acórdão com todos os votos dos Ministros que participaram do julgamento ainda não tinha sido disponibilizado pelo STJ. 
na ocasião houve investigação promovida pelo CNJ, que, contudo, não encontrou provas suficientes dando conta da efetiva ocorrência do ilícito. Todavia, mesmo depois disso, o nome da autora seguia indexado e associado aos dados "fraude em concurso para Juiz", ensejando a propositura da demanda mediante a alegação de que com isso estaria sendo afetada a privacidade e prejudicada a imagem pelo fato de já ocupar outro cargo público na seara jurídica.

Quanto às razões esgrimidas ao longo do percurso processual, importa destacar que, na sua sentença, o Magistrado que julgou a ação na primeira instância afastou a responsabilidade da empresa Google na condição de provedora de pesquisa, arguindo, em síntese, argumentos que vinham sustentando a orientação do STJ até então. Já em sede de apelação, tal resultado foi revertido, porquanto os integrantes do respectivo colegiado do Tribunal de Justiça do Rio de Janeiro entenderam que, dadas as circunstâncias do caso, os direitos de personalidade da então apelante deveriam prevalecer para o efeito de evitar a circulação, por tempo desarrazoado, de fatos noticiados que possam ter repercussão negativa na vida presente dos indivíduos. Dessa forma, o Tribunal de Justiça do Estado do Rio de Janeiro determinou que os referidos sites de busca instalassem filtros de conteúdo que desvinculassem o nome da autora (Promotora de Justiça) das notícias sobre a suposta fraude, sob pena de multa diária de $\mathrm{R} \$ 3$ mil.

Nos recursos especiais interpostos, os réus alegaram, em síntese:

a) violação de dispositivos do Código de Processo Civil e do Código Civil pelo fato de ter sido imposta obrigação técnica e juridicamente impossível;

b) que a obrigação imposta não implica utilidade alguma, porquanto a desvinculação do nome da recorrida dos sites de busca não impede a manutenção das matérias nas quais seu nome é referido na internet;

c) a aplicação do entendimento reiterado do Superior Tribunal de Justiça quanto à impossibilidade de responsabilizar os servidores de dados nessas condições;

d) que a ordem de filtragem dos resultados configura censura e ofende direitos dos consumidores que utilizam seus serviços de buscas.

Por fim, já em sede de julgamento dos Recursos Especiais, a $3^{\text {a }}$ Turma do STJ, por maioria de votos, deu-lhes parcial provimento apenas para o efeito de reduzir o valor da multa estabelecida aos recorrentes.

No que diz com as razões esgrimidas nos votos dos Ministros, é de se destacar que a eminente Relatora, Ministra Nancy Andrighi, manteve em termos gerais a posição sustentada em diversos julgados anteriores, nos quais havia negado pedidos de desindexação de conteúdos postados por terceiros e acessados mediante recurso a mecanismos de busca ofertados por provedores de pesquisa. No caso específico ora retratado, a Relatora destacou que a determinação da instalação de filtros nos mecanismos de busca configura uma espécie de censura privada prévia, categoricamente vedada pela 
CF, o que, por sua vez, impede que seja adotado no Direito brasileiro o parâmetro utilizado pelo TJUE no caso Google, ademais da circunstância de que no Brasil inexiste Lei Geral de Proteção de dados em vigor que dê guarida a medida de tal natureza. Além disso, novamente em sintonia com votos anteriores, ressaltou que também a Lei do Marco Civil da Internet não prevê tal possibilidade.

Acompanhando o voto da Relatora, o Ministro Ricardo Villas Boas Cuêva entendeu que a decisão do TJRJ teria negado vigência ao artigo 19 do Marco Civil da Internet, especialmente por ter imposto uma ordem genérica sem que tenha sido identificado de forma clara e específica o conteúdo tido como prejudicial e que pudesse viabilizar a sua localização, razão pela qual o autor do pedido de exclusão de dados deve indicar a URL. Ademais disso, de acordo com o dispositivo legal citado, os provedores apenas respondem civilmente por conteúdos postados por terceiros quando, uma vez notificados, não adotarem medidas para tornar indisponível o material tido como nocivo. Da mesma forma como o fez a Relatora, entende ser inaplicável o decidido pelo TJUE, visto que no caso Google vs. Agência Espanhola de Proteção de Dados e Mario Costeja Gonzales foi apenas determinada a remoção no mecanismo de busca, não da notícia veiculada em periódico.

Inaugurando a divergência, que acabou por prevalecer, o Ministro Marco Aurélio Belizze votou no sentido de dar provimento apenas parcial aos recursos especiais no sentido de reduzir o valor da multa aplicada. Quanto ao reconhecimento do direito ao esquecimento no caso concreto, manteve a decisão do TJRJ com base, em síntese, nos seguintes argumentos:

a) que não há diferença entre as normas aplicáveis na Europa e no Brasil, pois em ambos os casos se trata da responsabilidade dos provedores de pesquisas (mecanismos de buscas), que selecionam e hierarquizam informações a partir de algoritmos independentemente do conteúdo dos dados aos quais dão acesso;

b) que o Marco Civil da Internet dá sustentação à medida imposta pelo TJRJ, ainda que não esteja expressamente prevista, o que pode ser o caso em situações excepcionais quando o impacto do acesso às informações gerar um impacto desproporcional, designadamente quando se cuida de interesses de natureza privada e, mesmo quando presente interesse coletivo, à vista do transcurso de um largo espaço temporal desde a ocorrência dos fatos cuja divulgação na internet é tida como prejudicial;

c) no caso concreto, mesmo transcorridos dois anos dos fatos, o provedor seguia apontando como notícia mais relevante associada ao nome da autora da ação aquela relativa às supostas fraudes relacionadas ao concurso público para a Magistratura, sendo que mesmo depois de uma década tais fatos seguem disponibilizados como se inexistissem informações posteriores;

d) o pedido da autora é específico, no sentido de que o apontamento do seu nome deixe de ser usado como critério exclusivo, desvinculado de qualquer outro termo, relacionando-o ao mencionado fato desabonador de seus diretos de personalidade; 
e) à medida que o resultado aparece e é mantido pelo site o que se verifica é uma atividade de retroalimentação, porquanto ao realizar a busca pelo nome da autora e obter o link à referida notícia, o usuário do provedor irá acessar o conteúdo, o que, por sua vez, reforçará o sistema automatizado de que a página é relevante;

f) o acesso às informações não resta impedido, pois as fontes que as noticiam, inclusive referindo o nome da autora, seguem disponíveis na internet;

g) mediante a instalação dos filtros determinada, o que se está a evitar é o uso do nome da autora como critério exclusivo de busca seja acessada em primeiro lugar a informação sobre as fraudes noticiadas há mais de 10 anos.

Na sequência do Voto do Ministro Moura Ribeiro, que aderiu à divergência, coube ao Ministro Paulo Sanseverino proferir o voto de desempate em favor da divergência e pelo desprovimento dos recursos, esgrimindo as razões que seguem:

a) o caso concreto, distinto daqueles nos quais está em causa a responsabilidade de provedores de conteúdo, versa sobre o reconhecimento do direito de se evitar que, sendo feita a pesquisa mediante o uso dos mecanismos de busca dos provedores de pesquisa com referência apenas do nome da pessoa, sem qualquer outro critério vinculativo, as informações priorizadas seguissem sendo, transcorrido tanto tempo, os fatos que impactam os direitos da autora;

b) por tal razão, a exemplo do que ocorreu no caso Google vs. Mario Costeja Gonzalez, julgado pelo TJUE, e consideradas as peculiaridades do caso concreto, o direito à informação deve ceder em face da desproporcional afetação dos direitos de personalidade da autora.

À vista das decisões ora colacionadas, necessário proceder a uma avaliação crítica conjunta destas, o que será levado a efeito logo na sequência.

\section{Análise crítica das decisões do STJ}

Especialmente no que diz respeito à jurisprudência selecionada do STJ (que corresponde ao corte efetuado e justificado na introdução), ainda que tenha, em termos gerais, reconhecido um direito ao esquecimento, muitas questões seguem em aberto, não sendo também poucas e irrelevantes as críticas que se pode endereçar a vários dos julgados aqui apresentados, e isso mesmo pelo olhar de que, em princípio, é favorável ao reconhecimento em si de um direito ao esquecimento, inclusive na internet. 
Um primeiro aspecto a adentrar, muito embora diretamente aplicável ao ambiente da internet, diz respeito à responsabilidade dos provedores de pesquisa pelo fato de assegurarem o acesso a conteúdos considerados prejudiciais aos interesses e direitos de determinadas pessoas individual ou coletivamente consideradas, e mesmo interesses de instituições públicas e privadas.

Tal responsabilidade, que vinha sendo majoritariamente afastada, foi, como visto no segmento anterior, objeto de recente reconhecimento em decisão por maioria de um voto e que não necessariamente significa sua afirmação em casos posteriores, aderindo o STJ à posição aparentemente dominante na Europa, em especial por força da decisão do TJUE no caso Google vs. Mario Costeja e Agência Espanhola de Proteção de Dados e com amparo (pelo menos parcial) no Novo Regulamento Europeu de Proteção de Dados.

No caso brasileiro, a despeito da inexistência de previsão específica a um direito à desindexação em face dos provedores de pesquisa na legislação ordinária - inclusive na Lei do Marco Civil da Internet -, a responsabilidade dos provedores de pesquisa pode ser, para aqui firmar posição quanto a tal ponto ao menos em termos gerais, tida como afinada com o marco normativo em vigor, desde que considerado no seu conjunto e numa perspectiva teleológica e sistemática (SARLET, 2018). ${ }^{17}$

Com efeito, é possível sustentar que uma vez reconhecido na legislação um direito de apagamento em determinados casos, um direito à desindexação, tal como o fez o TJUE (também em face de uma lacuna legislativa) pode e mesmo deve ser reconhecido e assegurado, ainda que em casos excepcionais e tendo em conta determinados critérios, reconhecer um direito subjetivo à desindexação de determinados conteúdos dos mecanismos de busca na internet. Cabe relembrar aqui que se trata, ao fim e ao cabo, de uma possibilidade de se dar concretude à autodeterminação informativa e controle da utilização e divulgação de informações na internet, ainda mais em decorrência da grande dificuldade de se lograr o apagamento de determinadas informações de modo eficaz num ambiente caracterizado por tamanha diversidade e complexidade das estruturas e conexões (NOLTE, 2014, p. 2240).

O fato é que - na esteira da decisão Google do TJUE - os provedores de pesquisa, por meio dos mecanismos de busca, não podem ser considerados pura e simplesmente meros intermediários entre os usuários e v.g. os provedores de conteúdo, visto que os algoritmos utilizados para suas operações implicam uma forma de coleta e processamento de dados. Note-se que os mecanismos de busca vasculham de modo automático, continuado e sistemático na busca de informações publicadas na internet, para depois proceder a sua seleção, armazenamento e organização, por exemplo, no que diz com a hierarquização das informações buscadas em termos de ordem de aparição nas suas páginas (STEHMEIER; SCHIMKE, 2014).

Aqui poderia se agregar que independentemente dos aspectos técnicos referidos, incluindo o argumento de que as empresas e os programadores que produzem e utilizam algoritmos não

17 Para um maior desenvolvimento do tema (responsabilidade dos provedores de pesquisa e desindexação) - dentre a literatura disponível no Brasil, ver Gonçalves (2016). 
conhecem os dados em si e não controlam os resultados do seu processamento, isso não poderia levar a uma imunidade jurídica dos empreendimentos - no caso dos provedores de pesquisa -, já pelo simples fato de que isso implicaria uma impossibilidade de se protegerem os usuários e terceiros justamente em face dos maiores prejuízos causados precisamente pela massiva acessibilidade a conteúdos que possam causar efetivo e injustificado dano aos seus direitos de personalidade.

Assim, mesmo que não se enverede pelo terreno da responsabilidade civil, ao menos não quando os conteúdos são retirados em razão de ordem judicial, como se reconhece na jurisprudência do STJ, situação na qual se configura uma responsabilidade do tipo subjetivo, a possibilidade de em determinadas circunstâncias determinar a desindexação dos mecanismos de busca pode consistir em instrumento para assegurar - mesmo que de modo limitado - alguma efetividade do direito ao esquecimento na internet e, com isso, dar alguma proteção em concreto aos direitos de personalidade.

Ainda nesse contexto, calha observar que a matéria é objeto de previsão em diversos Projetos de Lei, já referidos, ora em andamento no Congresso Nacional, os quais preveem e regulamentam não só um direito ao esquecimento em termos gerais, mas também um direito à desindexação em face dos provedores de pesquisa, como é o caso do PL n. 2712/2015, que inclui no artigo $7^{\circ}$ da Lei do Marco Civil o direito

a remoção, por solicitação do interessado, de referências a registros sobre sua pessoa em sítios de busca, redes sociais ou outras fontes de informação na internet, desde que não haja interesse público atual na divulgação da informação e que a informação não se refira a fatos genuinamente históricos.

O mesmo ocorre em relação ao Projeto de Lei n. 1676/2015, de acordo com o qual se assegura o direito de exigir, independentemente de autorização judicial, dos meios de comunicação em geral, bem como dos provedores de conteúdo e de busca na internet, que deixem de veicular ou excluam material ou referências que os vinculem a fatos ilícitos ou comprometedores de sua honra.

Caso um direito à desindexação venha a ser consagrado pela via legislativa, e consolidada a orientação adotada pelo STJ no julgamento colacionado no item anterior (ressalvada, é claro, a possibilidade de vir a desindexação ser tida como constitucionalmente ilegítima pelo STF), isso não significa que não remanesçam importantes pontos a definir e que se revelam como altamente polêmicos, designadamente quanto ao objeto, limites, mas também aos instrumentos para a efetivação do direito ao esquecimento, ademais dos critérios para o seu reconhecimento e aplicação, questões, aliás, que guardam relação entre si.

Tendo em conta que o direito ao esquecimento, como manifestação particular da proteção da personalidade em termos gerais e de diversos direitos de personalidade específicos e considerando que em regra o seu reconhecimento implica afetação de outros direitos, princípios e bens jurídicos de estatura constitucional (com destaque para a liberdade de expressão e de informação), os problemas teóricos e práticos centrais dizem respeito à determinação dos seus limites e dos critérios para a sua aplicação aos casos concretos. 
Nesse contexto, verifica-se que em regra as decisões do STJ não dão a devida atenção para o problema, deixando - salvo quanto a um ou outro aspecto - de proceder a uma ponderação cuidadosa e pautada pelas peculiaridades do caso concreto, do impacto sobre os direitos fundamentais das medidas interventivas em causa, no sentido da avaliação da observância, ou não, dos critérios da proporcionalidade.

Uma exceção se verifica no caso Chacina da Candelária, no qual se apontou para o fato de que no Programa de Televisão impugnado poderia ter sido suprimida a identidade do autor da ação, compatibilizando a sua proteção no que diz com uma exposição pública constrangedora e a liberdade de informação. Também o argumento (utilizado num dos casos envolvendo o Google) de que com a desindexação dos mecanismos de busca, de igual modo se estaria obstaculizando o acesso ao direito de resposta exercido pelo autor da ação pode representar uma diretriz apta a auxiliar na solução de determinados casos concretos. $\bigcirc$ mesmo, por sua vez, se aplica ao argumento de que o comportamento da pessoa que se sentiu prejudicada contribuiu para que o resultado alegadamente danoso deva ser levado em conta no caso concreto, muito embora seja questionável se isso de fato deveria ter um peso determinante no caso julgado pelo STJ apresentado (imagens da intimidade, no caso, nudez).

Além dos critérios nominados, nas decisões do STJ foram manejados outros, como o maior ou menor transcurso do tempo entre os fatos, notícias, juízos de valor tidos como prejudiciais (casos Aída Curi, Chacina da Candelária e mesmo o caso da Promotora de Justiça absolvida por suposto envolvimento em fraudes em concurso público). Aliás, a própria circunstância de ter o autor da demanda (caso da Promotora de Justiça, do Magistrado supostamente envolvido em práticas pedófilas, caso Chacina da Candelária) sido absolvido em nível de processo disciplinar ou criminal foi utilizada como critério relevante a ser levado em conta na ponderação. Também a qualidade - maior ou menor importância e interesse público - da informação, a função exercida pela pessoa que se sentiu prejudicada, o nível de afetação de seus direitos fundamentais, com destaque para os direitos da personalidade (o que foi melhor desenvolvido no caso Chacina da Candelária), a relevância histórica e o correspondente direito à memória (caso Brilhante Ustra).

Especialmente questionável é o argumento, utilizado em sede de processos criminais, de que a não consideração (ou consideração com menor peso) de antecedentes relativos a condenações anteriores, por força da passagem do tempo, teria relação com um direito ao esquecimento, pois em causa não estava a não divulgação dos fatos ou a responsabilização de quem os divulgou. Isso, por sua vez, não significa que a reabilitação criminal não possa ser um critério relevante para o reconhecimento de um direito ao esquecimento, ainda mais quando a proibição da divulgação de tais dados encontra previsão expressa na legislação, como já referido na seção sobre a justificação de um direito ao esquecimento à luz do marco normativo brasileiro.

Todavia, embora se esteja perante alguns possíveis critérios para a aplicação do direito ao esquecimento e que também tem sido objeto de utilização em decisões proferidas por Tribunais de outros Estados e mesmo no caso Google do TJUE, trata-se de argumentos esgrimidos em geral de 
modo isolado e genérico, sem maior densidade, não afastando, no que aqui se entende, a correção substancial das críticas aqui tecidas em particular quanto ao modo de se realizar a ponderação e aplicar os critérios da proporcionalidade.

Nessa quadra, chama a atenção, ainda, que em geral nas decisões em que se reconheceu um direito ao esquecimento pouco ou nada se considerou a adequação, necessidade e a proporcionalidade em sentido estrito quanto aos meios utilizados para dar efetividade ao direito ao esquecimento (responsabilidade civil, desindexação/imposição do uso de filtros nos mecanismos de busca, exclusão de dados, etc.), o que se revela crucial para a obtenção de uma solução constitucionalmente consistente e que leve em conta também o impacto causado pelo uso de terminado meio sobre direitos e interesses colidentes.

Assim, por exemplo, no tocante à decisão do STJ de 08 de maio de 2018, já referida, não chegou a ser considerado - aspecto argutamente apontado por Carlos Affonso Souza em qualificado comentário da decisão (edição do JOTA de 13 de maio de 2018) - que a não indicação de endereços específicos (URLs) acaba impondo aos provedores de pesquisa um dever de monitoramento genérico para os provedores de pesquisa, ademais de que com isso se torna muito mais difícil a própria efetividade da decisão.

Particularmente relevante é o fato de que - novamente de acordo com as críticas assacadas por Carlos Affonso Souza - é mediante a instalação de filtros e a depender dos critérios utilizados (em razão da escolha de determinadas palavras-chave) corre-se o risco de se chegar a uma solução que não atenda às necessidades da parte que se sente prejudicada e em favor da qual se reconheceu um direito ao esquecimento, pelo fato de se filtrar de menos, ou - o que parece mais grave - impedir a exibição e divulgação de conteúdos lícitos e mesmo de interesse geral.

Além disso, a imposição da colocação de filtros nos mecanismos de busca representa, do ponto de vista técnico, uma intervenção mais intensa do que a mera desindexação de determinados links impedindo o acesso a informações pelos usuários. Note-se que no caso Google do Tribunal de Justiça da União Europeia, o que se reconheceu foi apenas o direito à desindexação. Portanto, também tal aspecto deixou de ser embutido como elemento a ser considerado na ponderação efetuada nos votos vencedores, pois poderia levar a resultado diverso, eventualmente no sentido da não imposição da instalação de filtros.

Particularmente relevante é que o direito ao esquecimento, na sua condição de direito fundamental, poderá abranger um leque diferenciado de posições subjetivas, cada uma com objeto próprio, mas que podem eventualmente vir a ser cumulativas. Com efeito, em primeira linha pode o direito ao esquecimento consistir em um direito de exigir o cancelamento (apagamento) de determinadas informações (dados) veiculadas nos meios de comunicação em geral e na internet em particular. Tal possibilidade, como já referido, já se encontra prevista na legislação brasileira, ainda que de modo limitado, no Código de Proteção do Consumidor e no Marco Civil da Internet. 
Outra alternativa, que se verificou ser particularmente controversa no Brasil, é a de assegurar ao titular do direito a prerrogativa de exigir, em face dos provedores de pesquisa da internet, a desindexação de determinados links dos respectivos mecanismos de busca. Da mesma forma, o direito ao esquecimento pode contemplar a retificação de informações ou mesmo a supressão da identidade dos que se sentem prejudicados.

A tais possibilidades se somam os instrumentos do direito de resposta e da indenização pelos danos causados pela difusão das informações tidas como prejudiciais, sem prejuízo ainda da responsabilidade criminal (v.g. nos casos de injúria, difamação e calúnia), tratando-se, contudo, de mecanismos que não implicam a supressão ou dificuldade de acesso a informações e que com isso poderiam levar a um processo de esquecimento na esfera social. Todavia, o direito de resposta, utilizado de modo proporcional, tem a vantagem de propiciar uma espécie de contraditório comunicativo assegurando a possibilidade de fornecer uma visão alternativa, ao passo que o recurso à indenização pode ser útil para o efeito de dissuadir novas violações dos direitos de personalidade.

É claro que cada uma das possibilidades indicadas, que já são em sua maioria objeto de previsão legal e jurisprudencial, enseja questões controversas, inclusive no plano de sua legitimidade constitucional. Em caráter ilustrativo, é de se mencionar aqui o efeito inibitório e mesmo silenciador que o manejo desproporcional de tais mecanismos poderá exercer em relação à liberdade de expressão, muito embora, no caso da internet, a disponibilização de formulários on-line para viabilizar de modo expedito o direito de resposta possa minimizar tal impacto.

Da mesma forma, tomando-se a sério os deveres de proteção estatais dos direitos fundamentais, o leque de alternativas é ainda maior, incluindo - para além da responsabilidade criminal e cível - a regulação e garantia por parte do Estado, v.g., da livre concorrência entre os meios de comunicação e atores da internet, criação de mecanismos e garantias procedimentais judiciais e extrajudiciais, dentre outras. Assim, tanto do ponto de vista da dimensão subjetiva quanto da objetiva (que interagem, complementam-se, mas que também podem entrar em rota de colisão), o que se percebe é que pode haver inclusive uma cumulação de medidas a depender do caso (apagamento, desindexação e responsabilização cível e criminal, por exemplo).

Tal aspecto cresce em importância quando se percebe que também os níveis (a intensidade) da afetação de direitos fundamentais e outros bens de estatura constitucional são diferenciados, o que carece de ser devidamente considerado quando do controle judicial das restrições, em especial no que se refere aos critérios da proporcionalidade. Com efeito, é possível afirmar que, ao menos em princípio, a determinação do apagamento de dados e a desindexação dos mecanismos de busca na internet são medidas mais gravosas (do ponto de vista do alcance da restrição da liberdade de expressão e informação) do que a mera supressão da identidade daquele que se sente prejudicado ou mesmo do que eventual retificação (a depender do caso e do alcance) de informações.

Relembre-se que também no que concerne ao direito ao esquecimento, a aferição da legitimidade da restrição deve levar em conta a natureza e o impacto da medida restritiva. Nessa 
perspectiva, além do teste da adequação, portanto, da capacidade de mediante tal medida se atingir o resultado pretendido, há que se avaliar as alternativas disponíveis para tanto e verificar qual o respectivo impacto, ou seja, a intensidade da restrição imposta consoante indicado anteriormente.

Nesse contexto e tendo em conta os desenvolvimentos anteriores e leque de possibilidades em tese disponíveis para dar efetividade ao direito ao esquecimento, afirmando a proteção da personalidade em face da liberdade de expressão e de informação, verifica-se que em regra as decisões do STJ não dão a devida atenção para o problema de uma cuidadosa diferenciação e avaliação de tais alternativas e de seu impacto sobre os direitos e interesses em causa no contexto de uma ponderação.

Outro ponto que merece destaque é que não se levou suficientemente em conta nas decisões (especialmente nas que envolvem a internet) a natureza do ato tido como prejudicial exame que deve ser conjugado com o do impacto das medidas que dão efetividade ao direito ao esquecimento -, como é o caso da distinção entre informações verídicas e inverídicas e mesmo de natureza ilícita, e seu caráter mais ou menos prejudicial (ou seja, a intensidade do dano).

Mas também outros critérios manejados nas decisões carecem de um maior refinamento quando de sua aplicação.

Isso, por exemplo, ocorre com o fato tempo, ou seja, o maior ou menor lapso temporal decorrido desde a ocorrência dos fatos cuja divulgação é tida como prejudicial. Embora o decurso do tempo possa representar um critério útil e relevante (mas não exclusivo) quando da ponderação, percebe-se que o seu manejo não foi necessariamente o melhor nos dois casos. No caso Aída Curi, é possível objetar que, dada a natureza traumática dos fatos (assassinato e estupro) e por mais que o tempo tenha transcorrido, os efeitos sobre os familiares próximos possam seguir sendo importantes e que, por conseguinte, sua rememoração pública possa potencializá-los. No caso Chacina da Candelária, por sua vez, como o autor da ação fora absolvido no processo criminal, a situação não se confunde com os casos de condenação criminal, em que já existe regramento legal impeditivo da divulgação dos antecedentes salvo para efeitos de novo processo criminal, ou mesmo como ocorreu no caso Lebach I, ocorrido na Alemanha, em que se tratava de pessoa condenada prestes a obter sua liberdade e que com a reconstituição dos fatos em programa televisivo poderia ter sua ressocialização gravemente comprometida.

Outro argumento esgrimido pelo STJ diz respeito ao conteúdo historicamente relevante da informação e o interesse público na sua divulgação. Em ambos os casos tal condição foi afirmada, mas ainda assim não resultou, no caso Chacina da Candelária, na improcedência da ação, posto que aqui o alegado esgotamento do valor informativo e os constrangimentos causados pela nova divulgação dos fatos acabaram fazendo pender a balança em favor do reconhecimento do pedido indenizatório. Note-se que nos dois casos se tratava de fatos verídicos, cujo valor histórico e informativo foi reconhecido, mas nos quais o critério do transcurso do tempo foi valorado de modo distinto por razões que não soam como suficientemente convincentes, especialmente no caso Chacina da Candelária. 
Nos casos concernentes ao ambiente da internet, há algumas peculiaridades a serem consideradas. No caso Xuxa, o fato em si - realização do filme retratando relações sexuais com um menor com 12 anos de idade - é verdadeiro, mas a imputação de pedofilia (levando-se em conta se tratar de uma representação) assumiu caráter distorcido e prejudicial à imagem e atividade profissional da autora da ação contra o Google. Já no caso da ex-funcionária demitida em decorrência de vídeos por ela mesma produzidos e que a retratavam em cenas íntimas, embora não se tenha também aqui colocado em causa a veracidade dos fatos e autenticidade dos vídeos, o que ocorreu pelo menos consoante à linha adotada pelo STJ - foi que se deu, na esfera da ponderação, maior peso ao argumento de que foi a própria autora da ação quem se descuidou e, portanto, contribuiu para a divulgação do material.

O que se percebe, a esta altura, é que embora os critérios relevância histórica e interesse público na informação, transcurso do tempo e esgotamento da vida útil da informação criminal tenham sido utilizados, as decisões são frágeis no que diz com a justificativa individualizada do seu peso na ponderação e mesmo de sua consistência intrínseca. Já os critérios da veracidade em si dos fatos e da forma de sua divulgação, o eventual conteúdo ofensivo e ilícito das manifestações, assim como o respectivo impacto sobre os direitos fundamentais da pessoa alegadamente prejudicada praticamente não foram objeto de análise pelo STJ.

Ainda nesse contexto, soa oportuno referir que uma das críticas ao direito ao esquecimento consiste que o seu reconhecimento - que se manifesta em especial nos casos de um direito ao apagamento de informações ou na sua desindexação dos mecanismos de busca - implicaria o comprometimento da memória coletiva e, por via de consequência, a potencial aniquilação de um direito à memória e à verdade histórica (SARMENTO, 2016, p. 11 e ss.). Em sentido contrário, contudo, há quem diga que o direito ao esquecimento não tem por objeto o apagamento de determinados fatos ou de apagar ou reescrever a história, porquanto cuida apenas do direito individual atribuído a alguém de se insurgir contra uma determinada projeção individualizada de sua pessoa, extraída de fatos e suas respectivas avaliações pretéritas, que lhe acarrete prejuízo atual relevante, impactando os seus direitos de personalidade (SCHREIBER, 2017a).

Sente-se que, contudo, a razão socorre apenas em parte ambas as posições. Como já dito, reconhecer um direito ao esquecimento não significa reconhecer um amplo direito ao apagamento de informações, tratando-se, no caso do conflito com a liberdade de expressão e informação e mesmo de um direito à memória, de um problema relacionado ao conteúdo e limites dos direitos fundamentais envolvidos. Por outro lado, também não é em toda extensão correto afirmar que no caso do direito ao esquecimento não se trata de apagar fatos ou reescrever a história e, portanto, apenas de se impugnar determinada projeção extraída de fatos e avaliações pretéritas. Com efeito, embora o fato concreto em si não possa ser apagado, porquanto materializado, informações (incluindo a mera retratação de fatos) e determinadas avaliações podem ser objeto, ao menos em certa medida, de um apagamento, 
o que não afasta a circunstância de que também - e mesmo quem sabe preponderantemente - o que esteja em causa é a insurgência contra projeções individualizadas a respeito de alguém.

Da mesma forma, chama a atenção que não se deu maior peso às situações que envolvem informações e manifestações que, embora possam ser legitimamente tidas como prejudiciais e de grande impacto sobre os diretos de personalidade na perspectiva individual, sejam relevantes do ponto de vista de sua historicidade e valor informacional, independentemente do decurso do tempo. Aqui sim seria possível adotar - pelo menos como um critério alternativo a ser avaliado caso a caso -, a exemplo do que se sugeriu no caso Chacina da Candelária, a supressão da identidade dos envolvidos, sem que com isso se coloque obstáculo ao livre e generalizado acesso ao conteúdo da informação.

Outro ponto a ser sublinhado e que igualmente não foi sequer referido nas decisões retratadas, diz respeito aos deveres de proteção estatais para com os direitos fundamentais na esfera da relação entre particulares, o que, no caso da proteção dos direitos de personalidade na internet assume particular relevância e implica problemas de complexa e difícil solução, o que também se aplica ao direito ao esquecimento.

Nessa senda, quando envolvidos interesses de atores privados poderosos do ponto de vista econômico e mesmo político (pela capacidade de exercer pressão e mesmo manipular os processos legislativos e regulatórios em geral, inclusive em escala internacional) - como é precisamente o caso do Google, Facebook e outros -, o que se verifica é um grande desequilíbrio entre as partes envolvidas na teia de relações jurídicas que se estabelecem entre usuários, provedores, etc. Além disso, não se deve desconsiderar que a concepção de que o ambiente digital é regido pela autonomia privada encontra forte crítica no fato de que boa parte dos bens e serviços disponibilizados é apenas acessível mediante contratos de adesão, sem falar no fato de que em virtude da necessidade gerada no sentido da utilização de diversos desses serviços em muitos casos se estabelece praticamente uma obrigação (fática) de contratar que literalmente esvazia a autonomia individual e o direito fundamental à livre autodeterminação informativa, reconhecido na CF e, conforme já referido, na legislação ordinária (HOFMANN-RIEM, 2017, p. 121-142).

Por tais razões, também no ambiente da internet e dos meios de comunicação em geral, não se pode admitir uma esfera de atuação livre dos direitos fundamentais, gerando uma espécie de imunidade, tanto mais perigosa - no que concerne a violações de direitos - quanto mais força tiverem os atores privados que operam nesse cenário. Por isso, um controle rigoroso das restrições a direitos fundamentais também na esfera das relações privadas, inclusive em caráter preventivo, levando em conta os deveres de proteção estatais também em face de perigos e riscos é de ser levado a efeito também pelos Tribunais, atentando em primeira linha para as opções legislativas, mas vigilantes no que concerne à sua eventual inconstitucionalidade e constitui sua tarefa primordial quando se trata da proteção dos direitos de personalidade e, portanto, do direito ao esquecimento como sendo sua particular expressão. Por sua vez, isso implica levar a sério as exigências do teste de proporcionalidade, não apenas no sentido da proibição de uma intervenção (restrição) excessiva do 
âmbito de proteção do direito fundamental afetado, mas também - como decorrência dos deveres de proteção - no sentido da proibição de uma proteção insuficiente de um ou alguns dos direitos fundamentais em causa (SCHLIESKY et al., 2014, p. 119 e ss.).

\section{Considerações finais e questões em aberto}

No que diz com o seu reconhecimento como um direito fundamental no Brasil, é possível afirmar que o direito ao esquecimento tem encontrado guarida tanto na literatura quanto em diversas decisões dos Tribunais Superiores brasileiros, tendo sido reconhecida, inclusive, a Repercussão Geral da matéria pelo STF, cuja decisão final terá, quando proferida, eficácia erga omnes e efeito vinculante em relação a todas as demais esferas do Poder Judiciário. Tal entendimento (embora sujeito ainda ao crivo do STF) encontra suporte no marco normativo - constitucional e legislativo - brasileiro, o que, todavia, não significa que o conteúdo, o modo de manifestação concreta e os limites do assim chamado direito ao esquecimento não sejam controversos e estejam ainda distantes de um tratamento adequado e consistente também no Brasil.

De acordo com o que se buscou demonstrar, em se reconhecendo em princípio a existência de um direito ao esquecimento, a legislação em vigor ainda é lacunosa e contempla apenas em parte as suas diversas dimensões. Se do ponto de vista do direito processual (incluindo o acesso à Justiça) já se verifica um investimento importante pelo legislador, o mesmo ainda não se pode dizer quanto ao conteúdo e limites do direito ao esquecimento, nem na sua perspectiva subjetiva e muito menos no que diz aos deveres de proteção estatais e sua concretização.

No caso dos projetos de lei em tramitação no Congresso Nacional, embora seja de saudar o fato de se prever uma regulamentação legal do direito ao esquecimento, que abarque o mundo digital e que, para além de um direito a exigir o cancelamento de informações inclua também um direito à desindexação junto aos mecanismos de busca, importa avaliar com cuidado os critérios estabelecidos. Em termos gerais, os projetos referem o caráter prejudicial da informação aos direitos de personalidade e a necessidade de demonstração de tal condição pelo autor do pedido. A ausência de relevância histórica e pública igualmente é objeto de previsão, assim como uma relativização da proteção em se tratando de pessoas que exercem cargos públicos. Do ponto de vista processual se faz referência a um procedimento direto dos usuários em face dos órgãos de comunicação, inclusive na internet, bem como, em caso de negativa - em sintonia com a orientação do STJ -, da necessidade de se buscar uma ordem judicial. Afora isso, é de se destacar a criminalização da publicação e divulgação de informações e manifestações prejudiciais, com penas maiores no caso da internet. Tal previsão, se aprovada, levanta alguns questionamentos, seja em relação à própria justificação constitucional da criminalização em si mesma, seja, uma vez superado tal ponto, sobre eventual desproporcionalidade de penas maiores no caso da internet, embora, a favor de tal solução, penda o argumento de que o poder de difusão e, portanto, de exposição e afetação é muito maior. 
Especificamente no que se refere à atuação do Poder Judiciário - aqui examinada com base nas decisões dos Tribunais Superiores -, é possível identificar uma ainda significativa falta de coerência e consistência nas decisões, em especial no que diz respeito aos critérios utilizados para reconhecer o direito ao esquecimento nos casos concretos e efetuar sua ponderação em face de direitos fundamentais conflitantes.

Relembre-se que embora o STJ tenha referido os critérios do transcurso do tempo, do caráter prejudicial da informação sobre a privacidade, honra e imagem das pessoas, a ausência de valor histórico, a baixa relevância informacional ou o seu esgotamento, e a ausência de interesse público, não se verificou qualquer esforço em precisar o conteúdo e alcance de tais referenciais. Da mesma forma, não se considerou a natureza da informação (manifestação), como o fato de ser ou não verídica e mesmo a sua substancial licitude penal. O mesmo é possível afirmar em relação ao recurso às regras legais em vigor aplicáveis ao direito ao esquecimento (proibição de divulgação de antecedentes criminais, dados negativos de consumidores, etc.). Até as exigências da proporcionalidade - que pressupõe também o exame da intensidade das restrições impostas aos direitos fundamentais em colisão - não foram levadas a sério.

Soma-se a isso o fato de que nos casos que não envolvem a internet - cuja importância para o presente texto se deve ao fato de que, a despeito da falta de maior fundamentação e consistência, discutiram critérios para a aplicação do direito ao esquecimento -, tratava-se em primeira linha de reconhecer um direito à indenização pelos danos causados pela divulgação de fatos considerados prejudiciais; não se discutindo um direito ao impedimento da divulgação, no todo ou em parte, é possível mesmo questionar se aqui se está a tratar efetivamente de um direito ao esquecimento no sentido próprio do termo, pois as informações veiculadas restaram intocadas e disponíveis ao amplo acesso dos interessados.

No tocante a um direito ao esquecimento no ambiente da internet, é de se saudar que o STJ, após uma fase mais restritiva, passou a reconhecer (pelo menos é o que se espera siga a ocorrer daqui para frente) a responsabilidade dos provedores de pesquisa e um correspondente direito (e dever) de desindexação de determinados links a conteúdos reconhecidos como de divulgação prejudicial aos direitos de personalidade.

Com isso, não se quer dizer que o cancelamento e, no caso dos provedores de pesquisa, a desindexação dos mecanismos de busca devam ser reconhecidos sem uma rigorosa avaliação das peculiaridades do caso concreto, sempre tendo em conta o impacto dos meios e as alternativas disponíveis para assegurar a proteção da personalidade em descuidar da liberdade de expressão e informação, bem como outros critérios relevantes, que ainda - como se viu também no caso brasileiro - aguardam um desenvolvimento adequado. O mesmo, contudo, se aplica ao reconhecimento de um direito à retificação de informações, de uma indenização na esfera da responsabilidade civil e, em menor escala, de um direito de resposta, os quais não podem assumir a condição de regra, porquanto 
também representam, no caso de um uso hipertrofiado, uma ameaça para as liberdades de expressão e de informação.

No caso do direito de resposta on-line, contudo, a exemplo dos formulários disponibilizados para os usuários requererem o apagamento ou desindexação, a utilização de instrumento dessa natureza asseguraria - com custo mais baixo - um meio ágil e eficaz para a contraposição da versão tida como correta por quem se sentiu prejudicado.

Dentre os problemas que envolvem os direitos ao cancelamento, retificação e desindexação (para além da discussão a respeito dos diversos critérios para o seu reconhecimento e aplicação no caso concreto) assume relevo a crítica - endereçada já em relação à decisão do TJUE no caso Google, mas também referida em decisões do STJ - de que a solução de atribuir aos provedores de pesquisa, e mesmo (para os casos de cancelamento) aos provedores de conteúdo e compartilhamento, a prerrogativa de decidirem quais dados cancelar ou quais links desindexar pode levar a um sistema de censura privada (HOLZNAGEL; HARTMANN, 2016, p. 228).

A adoção - como já praticada, dentre outros, pelo Google - de um modelo de formulários on-line à disposição do usuário (podendo o requerimento ser, ou não, acolhido pelo provedor) - limita, até determinado ponto, a discricionariedade dos provedores, mas ainda assim a decisão permanece ao nível das relações entre particulares. Uma forma de contornar uma parte do problema seria exigir que a outra parte, responsável pela postagem na internet do conteúdo tido como prejudicial, seja intimada para poder eventualmente impugnar o pedido, garantido, assim, o necessário contraditório, mas mesmo aqui não está resolvida a questão da proteção do direito de acesso à informação por parte de terceiros (HOLZNAGEL; HARTMANN, 2016, p. 228). ${ }^{18}$

Nesse contexto, não há como deixar de se tecer algumas - muito rápidas - considerações sobre uma das principais questões de fundo que dizem respeito ao equacionamento das tensões e colisões entre a proteção da personalidade e de um direito ao esquecimento e a liberdade de expressão e informação. Trata-se da adoção, ou não, por cada ordem jurídica, da tese de uma posição preferencial da liberdade de expressão e do seu respectivo alcance, aspecto que tem encontrado respostas bastante diferenciadas em diversas ordens jurídicas.

No caso brasileiro, embora na perspectiva estrita do texto constitucional, não há como afirmar com tanta tranquilidade a tese da posição preferencial da liberdade de expressão como uma exigência do constituinte. ${ }^{19}$ Contudo, em se examinando a jurisprudência mais recente do STF,

\footnotetext{
18 É verdade que o Google, depois da decisão do TJUE, além de dar guarida a boa parte dos pedidos de desindexação, tem por costume comunicar os provedores de pesquisa após a desindexação e apagamento dos resultados de busca, muito embora não exista, de acordo com o TJUE, uma obrigação jurídica nesse sentido e nem mesmo de assegurar a oportunidade prévia de manifestação e impugnação ao proprietário da página da Internet.

19 Note-se que ao mesmo tempo em que é proibida toda e qualquer forma de censura e a exigência de prévia licença para o exercício da liberdade de expressão, os direitos de personalidade, designadamente, os direitos à privacidade, intimidade, honra e imagem, foram expressamente gravados por sua condição de direitos invioláveis, o que, por sua vez, não foi expressamente afirmado em relação à liberdade de expressão. De fato, de acordo com o artigo $5^{\circ}$ " [...] IV - é livre a manifestação do pensamento, sendo vedado o anonimato; IX - é livre a expressão da atividade intelectual, artística, científica e de comunicação,
} 
bem como a posição de expressiva literatura (em que pese a existência de significativo dissenso), é possível sustentar que a tese da posição preferencial da liberdade de expressão e de informação tem prevalecido. ${ }^{20}$ Isso se manifesta também no que concerne o direito ao esquecimento, como foi explicitado em decisões já referidas do STJ - sem maior fundamentação - envolvendo a responsabilidade dos mecanismos de busca na internet (decisões em favor do Google), mas não encontra respaldo em todas as decisões do mesmo Tribunal envolvendo o direito ao esquecimento fora do domínio digital, como ocorreu no caso Chacina da Candelária, já referido.

Todavia, nenhum dos casos nominados envolvia a veiculação de informações (manifestações) evidentemente inverídicas ou de caráter em si ofensivo (injúria, difamação e mesmo calúnia), nem mesmo situações em que se configura o assim chamado discurso do ódio. Em especial no caso do último, não se registra decisão recente do STF, cujo principal precedente, de 2004, envolvendo a confirmação da condenação criminal por racismo de autor e editor de obra que negava o holocausto judeu durante a Segunda grande Guerra Mundial, justamente não sustenta a tese da posição preferencial da liberdade de expressão, ainda que três Ministros tenham encaminhado voto divergente (BRASIL, 2003).

De qualquer sorte, como no caso do reconhecimento de um direito ao esquecimento, especialmente naquilo que envolve posições subjetivas que impliquem o cancelamento de dados e/ou uma significativa dificuldade de acesso a eles, se está impondo uma carga particularmente restritiva sobre as liberdades de expressão e de informação, a diretriz de que medidas restritivas de direitos devem ser interpretadas restritivamente deve ser ainda mais tomada em sério (BARROSO, 2007).

Dito de outro modo, o reconhecimento de um direito ao esquecimento que envolva os mecanismos referidos (cancelamento e/ou desindexação) deve ter caráter excepcional e observar um conjunto de critérios que devem ser rigorosamente controlados nas diversas situações, o que assume - como já percebido - uma dimensão particularmente relevante na internet, em que a possibilidade de participação direta das pessoas nos processos comunicativos e informacionais imprescindível à democracia se manifesta com agudeza.

Assim, não poderá ser, portanto, qualquer manifestação que exponha aspectos da vida privada que justifique a invocação e proteção do direito ao esquecimento, de modo que, por ocasião do necessário balanceamento entre os direitos de personalidade e a liberdade de expressão e informação, o ônus argumentativo para fazer prevalecer os direitos de personalidade deve ser particularmente elevado, pois "existindo dúvida a respeito da legitimidade constitucional da restrição, é de se

independentemente de censura ou licença; X - são invioláveis a intimidade, a vida privada, a honra e a imagem das pessoas, assegurado o direito a indenização pelo dano material ou moral decorrente de sua violação; [...]"

20 E o caso da ADPF 130, Relator Ministro Carlos Britto, na qual a Lei de Imprensa editada sob a égide do Regime Militar foi considerada não recepcionada pela CF. Outros dois casos também acabaram por se alinhar com uma posição preferencial da liberdade de expressão, designadamente o assim chamado caso "marcha da maconha", no qual o STF entendeu que uma manifestação pública e coletiva em prol da legalização do consumo da maconha não poderia ser enquadrada no tipo penal da apologia ao crime (ADPF 187, Rel. Min. Celso de Mello, j. em 15.06.2011), e a decisão sobre as biografias não autorizadas (ADI 4815, Rel. Min. Cármen Lúcia, j. 10.06.2015). 
privilegiar a liberdade de expressão, parâmetro que não deve cair jamais em esquecimento." (SARLET, 2014, p. 473).

À vista do exposto, é possível afirmar que também no Brasil a determinação do conteúdo e alcance do assim chamado direito ao esquecimento se encontra em fase ainda embrionária, carecendo de uma reflexão cuidadosa e que saiba, seja no plano acadêmico (no qual, é preciso reconhecer, já se registram esforços dignos de nota), seja - com particular ênfase - na seara político-legislativa e jurisdicional, equacionar os problemas relacionados. Nesse sentido, além do desenvolvimento de parâmetros adequados, constitucionalmente legítimos e suficientemente seguros e eficazes, é imperioso que se mantenha um olhar voltado para as reais possibilidades de um direito ao esquecimento, dadas as peculiaridades da internet.

Isso remete, entre outros aspectos, para o problema da efetividade do direito ao esquecimento no sentido da eficácia das decisões que o venham a reconhecer, tanto do ponto de vista estritamente técnico, quanto do ponto de vista da jurisdição e do processo, podendo gerar uma incongruência entre os objetivos do reconhecimento de um direito ao esquecimento e a realidade, como, por exemplo, a dificuldade de impor as decisões judiciais no plano interno e além das fronteiras estatais.

Ainda nesse contexto situa-se o problema - não exclusivo dos conflitos que envolvem a internet - de um processo de competição (incluindo um conflito) de jurisdições, no plano interno das relações entre os diversos Estados (v.g. a negativa de um direito ao esquecimento num caso e o reconhecimento no outro ou a utilização de critérios distintos), mas também no plano das relações entre Tribunais de natureza supranacional (como é o caso do TJUE) e as cortes nacionais (UNESCO, 2014, p. 4-5, 13-14).

Além disso, por mais que se promova um desenvolvimento da regulação no plano interno dos Estados, faz-se necessária uma rede de cooperação de natureza transnacional e que envolva atores estatais, organizações internacionais, bem como os grandes empreendimentos da mídia em geral e da internet, em torno de pautas razoáveis e exequíveis, abarcando tanto uma regulação quanto o estímulo a uma autorregulação, preferencialmente regulada, nesse domínio (HOFFMANN-RIEM; LADEUR; TRUTE, 2003; HOFFMANN-RIEM, 2016).

É preciso salientar, todavia, que a criação de marcos regulatórios adequados no plano interno dos Estados por si só será sempre muito mais limitada (em se ficando apenas no nível doméstico) do que uma estrutura regulatória transnacional, ainda que também limitada quanto ao seu alcance e eficácia. Exemplo disso é o caso da União Europeia, com o novo regulamento de proteção de dados e sua prevista aplicação para além do território europeu, em especial no que diz com a transferência de dados, que também obriga os países receptores a tomarem medidas que sejam consistentes com as exigências estabelecidas pelo regulamento, caso quiserem manter uma série de transações com os estados que integram a União. Isso, contudo, é algo que aqui não se tem condições de desenvolver.

Da mesma forma, dada a globalização da internet e do fluxo de dados, a formação de ilhas de proteção mais rigorosa de dados pessoais (inclusive um regime mais aberto ao direito ao 
esquecimento) pode resultar em importantes distorções e assimetrias, incluindo desvantagens competitivas e de natureza econômica. Basta aqui, em caráter ilustrativo, lembrar a mudança da sede e mesmo de filiais por parte dos empreendimentos para escapar de uma regulação mais rigorosa, como ocorreu no caso do Facebook, que migrou para a Irlanda para escapar às regras da União Europeia em matéria de proteção de dados. Tais aspectos, por sua vez, igualmente remetem ao já referido problema de uma regulação em escala transnacional e à criação de esquemas de cooperação internacional, bem como de uma competição e mesmo conflito entre jurisdições.

Assim, fechando o texto, mas deixando muitas janelas em aberto, é possível afirmar que embora as dificuldades quanto à sua efetividade em termos práticos, o direito ao esquecimento pode e mesmo deve ser reconhecido, também no caso brasileiro, como um direito fundamental implícito e vinculado à proteção da dignidade humana e dos direitos de personalidade.

Urge, contudo, que o direito ao esquecimento seja objeto de cuidadosa regulamentação pelo legislador, determinando de modo claro o seu conteúdo e alcance (que, para a internet, deve contemplar tanto um direito ao apagamento de dados quanto à desindexação no caso dos mecanismos de busca), bem como estabelecendo critérios constitucionalmente consistentes e rigorosos para a sua aplicação.

Já do Poder Judiciário, em especial dos Tribunais Superiores (de modo a imprimir a necessária segurança jurídica e previsibilidade às decisões das instâncias inferiores), o que se espera é que ao mesmo tempo em que deem guarida ao direito ao esquecimento, procedam a um controle rigoroso de sua aplicação, em especial no que toca ao seu impacto sobre a liberdade de expressão e de informação, que, como já referido, deve seguir ocupando uma posição preferencial.

Com isso se estará apenas em pequena parte (dados os limites postos pela realidade em termos técnicos) respondendo, na perspectiva do Direito, aos problemas e desafios que envolvem a proteção dos direitos da personalidade na internet. Não nos parece - e esse é o caminho que vem sendo trilhado em outros países e na União Europeia - que seja um motivo suficiente para abrir mão de um direito ao esquecimento.

\section{Referências}

ALBERS, Marion; SCHIMKE, Anna. Vergessen im Internet. 2018.

ANDRADE, Fábio Siebeneichler de. Considerações sobre a tutela dos direitos da personalidade no Código Civil de 2002. In: SARLET, Ingo Wolfgang (Coord.). O novo Código Civil e a Constituição. 2. ed. Porto Alegre: Livraria do Advogado, 2006.

BARROSO, Luís Roberto. Liberdade de expressão versus direitos de personalidade. Colisão de direitos fundamentais e critérios de ponderação. In: SARLET, Ingo Wolfgang (Coord.). Direitos fundamentais, informática e comunicação: algumas aproximações. Porto Alegre: Livraria do Advogado, 2007. 
BOTELHO, Catarina Santos. Novo ou velho direito? - O direito ao esquecimento e o princípio da proporcionalidade no constitucionalismo global. Ab Instantia, a. V, n. 7, 2017.

BRANCO, Sérgio. Memória e esquecimento na internet. Porto Alegre: Arquipélago, 2007.

BRASIL. Lei $\mathrm{n}^{\circ} 12.965$, de 23 de abril de 2014. Estabelece princípios, garantias, direitos e deveres para o uso da Internet no Brasil. Diário Oficial da União, Brasília, DF, 24 abr. 2014.

BRASIL. Lei n. 8.069, de 13 de julho de 1990. Dispõe sobre o Estatuto da Criança e do Adolescente e dá outras providências. Diário Oficial da União, 16 jul. 1990.

BRASIL. Superior Tribunal de Justiça. REsp 1334097/RJ. Relator: Ministro Luis Felipe Salomão. Órgão Julgador: Quarta Turma. Julgamento em 28 maio 2013. Disponível em: <http:// www.stj.jus.br/SCON/jurisprudencia/doc.jsp?livre $=$ chacina $+d a+$ candelaria $\& b=A C O R \& p=-$ true\&l=10\&i=1>. Acesso em: 05 fev. 2018.

BRASIL. Superior Tribunal de Justiça. Resp. 1407271/SP. Relator: Ministra Nancy Andrighi. Órgão Julgador: Terceira Turma. Julgamento em 29 nov. 2013. Disponível em: <http://www.stj. jus.br/SCON/jurisprudencia/doc.jsp?livre $=r e s p+1407271 \& b=A C O R \& p=$ true $\& t=J U R I D I-$ CO\&l=10\&i=4 >. Acesso em: 05 fev. 2018.

BRASIL. Superior Tribunal de Justiça. Resp. 1593873/SP. Relator: Ministra Nancy Andrighi. Julgamento em 10 nov. 2016. Disponível em: <http://www.stj.jus.br/SCON/jurisprudencia/toc.jsp?livre $=$ resp $+1593873 \& \&$ tipo_visualizacao $=$ RESUMO\&b $=$ ACOR\&thesaurus $=J U R I D I C O \& p=-$ true >. Acesso em: 06 fev. 2018.

BRASIL. Superior Tribunal de Justiça. Resp. 1642560/SP. Relator: Ministro Marco Aurélio Belizze. Julgamento em 12 set. 17. Disponível em: <http://www.stj.jus.br/SCON/jurisprudencia/toc.jsp? livre $=$ resp $+1642560 \& \&$ tipo_visualizacao $=$ RESUMO\&b=ACOR\&thesaurus $=$ JURIDICO\&p $=-$ true>. Acesso em: 05 fev. 2018.

BRASIL. Supremo Tribunal Federal. HC no 82424. Relator: Ministro Moreira Alves. Relator p/ Acórdão: Ministro Maurício Corrêa. Órgão Julgador: Tribunal Pleno. Julgamento em 17 set. 2003. Disponível em: <http://stf.jus.br/portal/processo/verProcessoAndamento.asp? numero=82424\&classe $=\mathrm{HC} \&$ codigoClasse $=0 \&$ origem $=J U R \&$ recurso $=0 \&$ tipoJulgamento $=\mathrm{M}>$. Acesso em: 05 fev. 2018.

BUCHHOLZ, Gabriele. Das "Recht auf Vergessen im Internet - Eine Herausforderung für den demokratischen Rechtstaat". Archiv des öffentlichen Rechts (AÖR), Tübingen: Mohr-Siebeck, v. 140, 2015.

CACHAPUZ, Maria Cláudia Mércio; CARELLO, Clarissa Pereira. O Direito ao Esquecimento no âmbito das relações entre particulares. In: SANTOS, Ricardo Soares Stersi dos; FERREIRA, Jussara Suzi Assis Borges Nasser; VILAS BOAS, Daniel Rivorêdo (Coord.). Direito Privado, Formas de Resolução de Controvérsias e Direitos Fundamentais. Florianópolis: CONPEDI, 2015.

CARELLO, Clarissa Pereira. Direito ao Esquecimento. Parâmetros Jurisprudenciais. Portão: Prismas, 2018.

CARO, Maria Álvares. Derecho al Olvido en Internet: el nuevo paradigma de la privacidad en la era digital. Madrid: Editorial Reus, 2015. 
CONSALTER, Zilda Mara. Direito ao Esquecimento. Proteção da intimidade e ambiente virtual. Curitiba: Juruá, 2017.

DECHENAUD, David. Le droit à l'oubli numérique: donnés normatives - approche comparée. Bruxelles: Éditions Larcier, 2015.

DIESTERHÖFT, M. Das Recht auf medialen Neubeginn: Die »Unfähigkeit des Internets zu vergessen" als Herausforderung für das allgemeine Persönlichkeitsrecht. Beiträge zum Informationsrecht. Freiburg: Duncker \& Humblot, 2014. v. 33.

ESPOSITO, Elena. Algorithmic memory and the right to be forgotten on the web. Big Data \& Society, n. 2, p. 1-11, jan./fev. 2017. doi: 10.1177/2053951717703996

FERREIRA NETO, Arthur M. Direito ao Esquecimento na Alemanha e no Brasil. In: MARQUES, Claudia Lima; BENICKE, C Christoph; JAEGER JUNIOR, Augusto. (Coord.). Diálogo entre o Direito Brasileiro e o Direito Alemão. Fundamentos, métodos e desafios de ensino, pesquisa e extensão em tempos de cooperação internacional. Porto Alegre: RJR, 2016.

GONÇALVES, Luciana Helena. O direito ao esquecimento na era digital: desafios da regulação de desvinculação de URLs prejudiciais a pessoas naturais nos índices de pesquisa dos buscadores horizontais. Dissertação (Mestrado em Direito e Desenvolvimento)-Escola de Direito da Fundação Getúlio Vargas, São Paulo, 2016. Disponível em: <http://bibliotecadigital.fgv.br/dspace/handle/10438/16525>. Acesso em: 06 fev. 2018.

HASSLER, Théo. Droits de la personnalité: rediffusion et droit à l'oubli. Recueil Dalloz, n. 40, p. 2829-2832, 2007.

HEYLLIARD, Charlotte. Le droit à l'oubli sur Internet. Mémoire de Master 2 recherche, Universite Paris-Sud, Faculté Jean Monnet - Droit, Économie, Gestion, 04 dez. 2012. Disponível em: <www. lepetitjuriste.fr>. Acesso em 14 fev. 2018.

HOFFMANN-RIEM, Wolfgang. Regulierte Selbstregulierung im digitalen Kontext. In:FEHLING, Michael; SCHLIESKY, Utz. (Ed.). Neue Macht- und Verantwortungsstrukturen in der digitalen Welt. Baden-Baden: Nomos, 2016. p. 27-51. Disponível em: <www.law-school.de/...riem/.../407>. Acesso em 14 fev. 2018.

HOFFMANN-RIEM, Wolfgang; LADEUR, Karl-Heinz; TRUTE, Hans-Heinrich (Coord.). Innovationsoffenne Regulierung des Internets. Baden-Baden: Nomos, 2003.

HOFMANN-RIEM, Wolfgang. Reclaim Autonomy: Die Macht digitaler Konzerne. In: AUGSTEIN, Jakob (Ed.). Reclaim Autonomy. Selbstermächtigung in der digitalen Weltordnung. Frankfurt am Main: Suhrkamp, 2017.

HOLZNAGEL, Bernd; HARTMANN Sarah. Das 'Recht auf Vergessenwerden' als Reaktion auf ein grenzenloses Internet - Entgrenzung der Kommunikation und Gegenbewegung. MMR, 2016.

KELLY, Michael J.; SATOLA, David. The Right to be Forgotten. Law Review, University of Illinois, n. 1, p. 1-65, 2017.

LEPAGE, Agathe. Droit á L'oubli: une jurisprudence tâtonnante. Recuiel Dalloz, 2001.

MALDONADO, Viviane Nóbrega. Direito ao Esquecimento. São Paulo: Novo Século, 2017. 
MARTINELLI, Silvia. Diritto all'oblio e motori di ricerca. Milano: Giuffré, 2017.

MARTINEZ, Pablo Dominguez. Direito ao Esquecimento: A Proteção da Memória Individual na Sociedade da Informação. Rio de Janeiro: Lumen Juris, 2014.

MAYER-SCHÖNBERGER, Viktor. Delete. The Virtue of Forgetting in the Internet. 2. ed. Princeton: Princeton University Press, 2011.

MORAES, Maria Celina Bodin de. Danos à pessoa humana. Uma leitura civil-constitucional dos danos morais. 2. ed. Rio de Janeiro: Processo, 2003.

NOLTE, Norbert. Das Recht auf Vergessenwerden - mehr als nur ein Hype? NJW, n. 31, p. 22382242, 2014.

RODOTÀ, Stefano. Il Mondo nella rete. Quali i diritti, quali i vincoli. Roma: Editori Laterza, 2014.

RODRIGUES JUNIOR, Otávio Luiz. Brasil debate o direito ao esquecimento desde 1990. CONJUR - Consultor Jurídico, 27 nov. 2013. Disponível em: <https://www.conjur.com.br/2013-nov-27>. Acesso em: 06 fev. 2018.

SARLET, Ingo Wolfgang. A eficácia dos Direitos Fundamentais. Uma teoria geral dos direitos fundamentais na perspectiva constitucional. 12. ed. Porto Alegre: Livraria do Advogado, 2015.

SARLET, Ingo Wolfgang. Direitos Fundamentais em Espécie. In: SARLET, Ingo Wolfgang; MARINONI, Luis Guilherme; MITIDIERO, Daniel. Curso de Direito Constitucional. 3. ed. São Paulo: Revista dos Tribunais, 2014.

SARLET, Ingo Wolfgang. Vale a pena relembrar o que estamos fazendo com o direito ao esquecimento. Revista Consultor Jurídico - CONJUR, 26 jan. 2018. Disponível em: < https://www.conjur. com.br/2018-jan-26/direitos-fundamentais-vale-pena-relembrar-fizemos-direito-esquecimento $>$. Acesso em: 06 fev. 2018.

SARMENTO, Daniel. Liberdades Comunicativas e "Direito ao Esquecimento" na ordem constitucional brasileira, parecer consultivo. Revista Brasileira de Direito Civil, v. 7, p. 190-232, jan./mar. 2016. Disponível em: <https://rbdcivil.ibdcivil.org.br/rbdc/article/view/76/70>. Acesso em: 06 fev. 2018.

SCHLIESKY, Utz. Schutzpflichten und Drittwirkung im Internet. Das Grundgesetz im digitalen Zeitalter. Baden-Baden: Nomos, 2014.

SCHREIBER, Anderson. As três correntes do direito ao esquecimento. JOTA, 18 jun. 2017a. Disponível em: <https://www.jota.info/opiniao-e-analise/artigos/as-tres-correntes-do-direito-ao-esquecimento-18062017>. Acesso em: 05 fev. 2018.

SCHREIBER, Anderson. Direito ao esquecimento: críticas e respostas. Jornal Carta Forense, 04 set. 2017b. Disponível em: <http://www.cartaforense.com.br/conteudo/colunas/direito-ao-esquecimento-criticas-e-respostas/17830 >. Acesso em: 05 fev. 2018.

SCHREIBER, Anderson. Direitos da Personalidade. 3. rev. e atual. São Paulo: Atlas, 2014. 
SOLOVE, Daniel. Speech, Privacy and reputation on the internet. In: NUSSBAUM, Martha; LEVMORE, Saul (Coord.). The Offensive Internet: Speech, Privacy and Reputation. Cambridge: Harvard University Press, 2011.

STEHMEIER, Marinus; SCHIMKE, Anna. Internet-Suchmaschinen und Datenschutz. Zugleich eine Besprechung von EUGH C-131/12 Google Spain und Google. UFITA. Archiv für Uhrheber-und Medienrecht. Sonderdruck aus Band 2014/III, Bern: Stämpfli Verlag AG, 2014.

TEPEDINO, Gustavo. Temas de Direito Civil. Rio de Janeiro: Renovar, 1999.

UNESCO. Online Privacy and Freedom of Expression. IDPC - The International Programme for the Development of Communication. Paris, nov. 2014. Disponível em: < https://unesdoc.unesco.org/ images/0022/002301/23017E.pdf>. Acesso em: 14 fev. 2018.

UNIÃO EUROPEIA. Parlamento Europeu e Conselho. Regulamento (UE) 2016/679 do Parlamento Europeu e do Conselho de 27 de abril de 2016, relativo à proteção das pessoas singulares no que diz respeito ao tratamento de dados pessoais e à livre circulação desses dados e que revoga a Diretiva 95/46/CE (Regulamento Geral sobre a Proteção de Dados). Disponível em: < http://eur-lex.europa. eu/eli/reg/2016/679/oj>. Acesso em: 06 fev. 2018.

WEISMANTEL, Jan. Das "Recht auf Vergessenwerden" im Internet nach dem "Google-Urteil" des EuGHBegleitung eines offenen Prozesses. Berlin: Duncker \& Humblot, 2017.

Data da submissão: 25 de junho de 2018 Avaliado em: 02 de julho de 2018 (AVALIADOR A) Avaliado em: 09 de julho de 2018 (AVALIADOR B) Avaliado em: 10 de julho de 2018 (AVALIADOR C) Avaliado em: 26 de junho de 2018 (AVALIADOR D) Aceito em: 10 de julho de 2018 